\title{
New Insights to Zinc Biofortification of Wheat: Opportunities to Fine-tune Zinc Uptake, Remobilization and Grain Loading
}

\author{
Chandima Kamaral ${ }^{1}$, Stephen Neate $^{2}$, Niroshini Gunasinghe ${ }^{1}$, Paul Milham ${ }^{3}$, David \\ Paterson $^{4}$, and Saman Seneweera ${ }^{1}$ \\ ${ }^{1}$ University of southen Queensland \\ ${ }^{2}$ University of Southern Queensland \\ ${ }^{3}$ Western Sydney University Hawkesbury Institute for the Environment \\ ${ }^{4}$ Australian Synchrotron Holding Company Pty Ltd
}

June 2, 2020

\begin{abstract}
Wheat contains low grain zinc $(\mathrm{Zn})$ due to its genetics and the physiochemical properties of the soil in which it is grown. Consequently, where wheat forms a major part of the human diet, bioavailable $\mathrm{Zn}$ is below dietary requirements. Understanding the regulation of genes responsible for cellular Zn-transport, particularly those responsible for the control of the biosynthesis pathway of nicotianamine, provides an opportunity to increase Zn loading into the grain. Decreasing the levels of phytic acid, an inhibitor of $\mathrm{Zn}$ absorption in humans, provides another opportunity to increase the bioavailability of grain Zn. Synchrotron X-ray fluorescence microscopy clearly demonstrated that the crease region of the wheat grain is a major bottleneck to $\mathrm{Zn}$ loading in the endosperm. Higher expression of $\mathrm{Zn}$ transporter families, particularly metal tolerance proteins and yellow stripe like transporter families in the aleurone layer are also likely to play a major role in determining grain Zn content. Finally, anatomical barriers in the vascular region at the base of the wheat grain are a major limitation to Zn loading. Modification of any of these traits through traditional plant breeding or gene editing provides an opportunity to increase the $\mathrm{Zn}$ concentration in wheat grain.
\end{abstract}

\begin{abstract}
Wheat contains low grain zinc $(\mathrm{Zn})$ due to its genetics and the physiochemical properties of the soil in which it is grown. Consequently, where wheat forms a major part of the human diet, bioavailable $\mathrm{Zn}$ is below dietary requirements. Understanding the regulation of genes responsible for cellular Zn-transport, particularly those responsible for the control of the biosynthesis pathway of nicotianamine, provides an opportunity to increase Zn loading into the grain. Decreasing the levels of phytic acid, an inhibitor of Zn absorption in humans, provides another opportunity to increase the bioavailability of grain Zn. Synchrotron $\mathrm{X}$-ray fluorescence microscopy clearly demonstrated that the crease region of the wheat grain is a major bottleneck to $\mathrm{Zn}$ loading in the endosperm. Higher expression of Zn transporter families, particularly metal tolerance proteins and yellow stripe like transporter families in the aleurone layer are also likely to play a major role in determining grain Zn content. Finally, anatomical barriers in the vascular region at the base of the wheat grain are a major limitation to Zn loading. Modification of any of these traits through traditional plant breeding or gene editing provides an opportunity to increase the $\mathrm{Zn}$ concentration in wheat grain.
\end{abstract}

Key Words : Zinc, wheat, biofortification, Zn speciation, Zn transporters, grain Zn loading

Abbreviations: (DTPA) diethylenetriaminepentaacetic acid, (DMA) 2'-deoxy mugineic, (HMA) $\mathrm{P}_{1 \mathrm{~B}^{-}}$ ATPases: also known as heavy metal ATPases, (MA) mugineic acid, (CDF) cation diffusion facilitators family transporters also known as (MTP) metal tolerance proteins, (NA) nicotianamine, (NAS) nicotianamine 
synthase, (NAM) No apical meristem also known as GPC genes, (NAAT) nicotianamine aminotransferase, (NRAMP) natural resistance associated macrophage protein, (OsFer) ferritin gene, (PA) phytic acid, (QTL) quantitative trait loci, (SAM) S-adenosyl-L-methionine, (VIT) vacuolar iron transporters, (XFM) x-ray fluorescence microscopy, (YSL) yellow stripe like transporter family, (ZIP) Zn/Iron -regulated transporter like proteins

Running head: Zinc biofortification of wheat

\section{1.) INTRODUCTION:OPPORTUNITIES AND CHALLENGES}

Wheat (Triticum aestivum ) is grown over more land area than any other cereal, and in 2019, world wheat production was estimated to be 760 million tonnes (FAO, 2019). Wheat grain contains $60-70 \%$ starch and is an important source of calories. It also provides approximately $20 \%$ of the world's daily dietary intake of protein, $25 \%$ of the human intake of zinc $(\mathrm{Zn})$, and $44 \%$ of the iron $(\mathrm{Fe})$ (Henderson et al., 2007; Shewry, 2009).

The human population is at risk of inadequate Zn intake, with $17 \%$ of the global population and $30 \%$ of the South Asian population recognized as Zn deficient (Maxfield \& Crane, 2019). Low levels of bioavailable dietary Zn cause adverse physiological impacts, metabolic diseases and severe health complications (J. G. White \& Zasoski, 1999). Severe deficiency symptoms are readily detectable, but subclinical deficiency is difficult to detect (McClung, 2019; Sandstead, 2012). Therefore, identifying sensitive biomarkers is needed to identify people at risk. As wheat provides a large portion of the daily calorie intake in rural communities in many developing countries (Cakmak \& Kutman, 2018), human Zn deficiency could be addressed by providing access to wheat grains with higher bioavailable grain Zn content.

Soil is the primary source of Zn for the wheat plant, although the plant can also absorb foliar applied Zn (Dhaliwal, Ram, Shukla, \& Mavi, 2019). Plant available soil Zn is determined by the forms of Zn present in the soil, for example, water soluble, adsorbed, exchangeable, colloidal and organic matter pools (Alloway, 2008). More than $90 \%$ of soil $\mathrm{Zn}$ is insoluble and consequently unavailable for plant uptake. Exchangeable $\mathrm{Zn}\left(\mathrm{Zn}^{2+}\right.$ and $\left.\mathrm{ZnOH}^{+}\right)$in the soil is typically in the range of $0.1-2 \mathrm{mg} \mathrm{kg}^{-1}$, which is much less than plant requirements (Barber, 1995); therefore, plants should have evolved efficient mechanisms to acquire soil $\mathrm{Zn}$. Nonetheless, half of the world's wheat is cultivated on soils whose plant available $\mathrm{Zn}$ is so low that wheat fails to achieve its growth potential (Cakmak, 2008), including large areas in India, Sri Lanka, Turkey, China and Australia (Alloway, 2008; Cakmak, 2008; Sillanpää, 1982). Zinc deficiency in soils decreases Zn uptake and loading into the wheat grain (Rehman, Farooq, Ozturk, Asif, \& Siddique, 2018); however, detailed understanding of the effects is limited.

\section{1) Biofortification}

P. J. White and Broadley (2005) defined biofortification as theprocess of increasing the bioavailable concentrations of an element in edible portions of crop plants through agronomic intervention or genetic selection . Compared to physical-fortification, biofortification is considered the more practical and environmentally friendly method to improve bioavailable micronutrient density in food crops as it is a one-time investment that can easily be adopted across landscapes (Meenakshi et al., 2010; Saltzman et al., 2013; Yaseen \& Hussain, 2020). Further, in the recent past, the global benefits acquired from biofortified cereals have been widely reported (Glahn et al., 2017; Kaur, Kaur, \& Mavi, 2020). However, as soil Zn is gradually depleted due to crop removal, physical biofortification is inevitable.

In terms of human nutrition, wheat is an ideal candidate for biofortification since it is the staple cereal for more than half of the world population and provides a substantial proportion of the daily Zn requirement (R. P. Singh \& Velu, 2017). Moreover, increase in grain Zn concentration is accompanied by an accumulation of other nutrients such as Fe, Mn, Ca and K (Fernando, Panozzo, Tausz, Norton, Fitzgerald, et al., 2014; Fernando et al., 2012). Notably, there are high positive correlations occur between grain Zn and Fe content 
(Cakmak et al., 2004; Velu et al., 2019; Velu, Singh, Huerta-Espino, Peña-Bautista, \& Ortiz-Monasterio, 2011). Further, over-expressed ferritin gene (Osfer2) facilitates increased Fe and $\mathrm{Zn}$ levels in the grain of basmati rice cv. Pusasugandh II (Paul, Ali, Gayen, Datta, \& Datta, 2012). All these findings suggest that through increasing grain $\mathrm{Zn}$ concentration, the concentrations of $\mathrm{Fe}, \mathrm{Mn}$, and $\mathrm{Ca}$ may also be improved; however, a mechanism for multiple nutrient accumulation is obscure. One possibility is that divalent cations share some transporters to uptake, transport, remobilization of Zn (Caldelas \& Weiss, 2017).

Bioavailability of grain $\mathrm{Zn}$ in the human digestive system is mainly determined by the concentration of phytic acid (PA), which strongly binds metallic ions such as Fe, Zn, K, Mg (Perera et al., 2019; Perera, Seneweera, \& Hirotsu, 2018). Wild wheat populations show a large genetic variability in nutrient accumulation and bioavailability (Bilgrami et al., 2017; Rawat et al., 2009), whereas in present day cultivars, Zn accumulation is less, perhaps due to the breeding focus on yield rather than quality (Fan et al., 2008; Murphy, Reeves, \& Jones, 2008).

\subsection{1) Agronomic Zn biofortification}

Increases in plant Zn can be achieved through fertilizer application (soil and/or foliar) and appropriate crop rotation (De Valença, Bake, Brouwer, \& Giller, 2017). Green manure applications increase Zn content in wheat grain, and nutrient release follows decomposition rate (Gruter, Meister, Schulin, \& Tandy, 2018). Soil applications of Zn fertilizer can raise grain Zn concentration in wheat three or four-fold (Cakmak, 2008), and one-off soil amendments give persistent benefits in many soil types. Nonetheless, there are challenges, including: the cost, and the effects of formulation, rate and time of application, and the risk of over-application creating Zn toxicity (Cakmak, 2008). Foliar Zn application can efficiently raise Zn levels in wheat grain (Ramzan et al., 2020; Xia et al., 2018) as foliar applied Zn can translocate efficiently to the endosperm (Ajiboye et al., 2015).

\subsection{2) Genetic biofortification}

Selective breeding, or genetic biofortification, creates new cultivars with increased levels of micronutrients (Garcia-Oliveira, Chander, Ortiz, Menkir, \& Gedil, 2018). However, the genetic variability existing is claimed to be inadequate to support development of cultivars having high grain Zn concentration (HarvestPlus, 2019). However, $\mathrm{Cu}$ et al. (2020) and Velu et al. (2019) disagree, and genetic biofortification through screening of natural genetic variation has been identified as the most sustainable and cost-effective way to deliver increased Zn to vulnerable populations globally (Pfeiffer \& McClafferty, 2007). Fortunately, (Ramzan et al., 2020 ) found that the relationship between grain yield and $\mathrm{Zn}$ concentration is not negative, indicating that Zn biofortification targets can be achieved without compromising yield. Molecular approaches such as gene identification, gene mapping and molecular markers can assist in developing micronutrient rich crop varieties (Bouis \& Saltzman, 2017; Velu et al., 2018).

Genetic engineering is a promising technology, which allows for the improvement of the nutritional quality of staple crops by transferring desirable, heritable traits between unrelated plant species (De Steur, Demont, Gellynck, \& Stein, 2017). It can be used to overcome the limitation of narrow genetic variation or the presence of hybridization barriers (Giri \& Praveena, 2015). For instance, transgenic maize plants with reduced levels of phytate, and transgenic rice with increased numbers of aleurone cell layers, have been genetically engineered (J. Liu et al., 2018; Shukla et al., 2009).

\subsection{3) Zinc in wheat grain}

More than 6000 wheat genotypes have been tested for grain $\mathrm{Zn}$ concentration and a large genetic variation (11.7-117 $\mathrm{mg} \mathrm{kg}^{-1}$ ) has been reported (Velu, Ortiz-Monasterio, Cakmak, Hao, \& Singh, 2014); however, much of this variation may be environmental in origin (Fernando, Panozzo, Tausz, Norton, Neumann, et al., 2014; 
Velu et al., 2018). Indeed, although some breeding lines accumulate $\mathrm{Zn}$ in the range of $55-102 \mathrm{mg} \mathrm{kg}^{-1}$ (Hao, Velu, Pena, Singh, \& Singh, 2014; Velu, Tutus, et al., 2017), the Zn content in the grain of most wheat cultivars is 20-35 mg kg-1 (Cakmak et al., 2004; Rengel, Batten, \& Crowley, 1999). Zinc is heterogeneously distributed in wheat grain, with the levels being highest $\mathrm{Zn}$ in the aleurone layer and embryo, and lowest in the endosperm (Ozturk et al., 2006). This distribution pattern causes a significant proportion of grain $\mathrm{Zn}$ to be removed during milling, and the $\mathrm{Zn}$ concentration is further reduced in white flour, which contains 5-10 mg Zn kg-1 , far below human dietary requirements for a staple dietary carbohydrate (Cakmak, Pfeiffer, \& McClafferty, 2010). This is particularly important as most wheat flour-based products are made from white flour (Shewry, 2009). Antinutrients such as phytate can lower the bioavailability of Zn in wheat grain; therefore, both phytate and Zn levels are important to Zn bioavailability.

\section{2.) SPECIATION-REGULATED ZINC CELLULAR TRAFFICK- ING FOR BIOFORTIFICATION}

Strategies to increase the bioavailability of minerals in staple crops must take their chemical speciation into account. Zinc forms chemical complexes (Zn species) with organic molecules (ligands) through the sharing of one or more electrons. The formation of low molecular weight $\mathrm{Zn}$ complexes effectively facilitates intraand inter- cellular Zn transport from root to shoot and to the developing grain (Sinclair \& Kramer, 2012). A significant fraction of $\mathrm{Zn}$ and other micronutrients taken up by plants is present as low molecular weight organic complexes (Figure 1). Zn complexes within the plant and soil exhibit different characteristic in different environments (Impa \& Johnson-Beebout, 2012), but this behaviour has not been closely studied. We argue that $\mathrm{Zn}$ speciation should be taken into account when attempting to increase Zn content and $\mathrm{Zn}$ bioavailability in the wheat grain. In the following section, we summarise routes of Zn transport and accumulation in wheat plants, discussing $\mathrm{Zn}$ species in the xylem, phloem and grain and how $\mathrm{Zn}$ species influence bioaccumulation of $\mathrm{Zn}$ in the grain.

Zinc species facilitate plant function by maintaining intercellular acid/base equilibrium and electron transfer reactions (Alvarez-Fernandez, Diaz-Benito, Abadia, Lopez-Millan, \& Abadia, 2014). A excess of free $\mathrm{Zn}^{2+}$ is however toxic in the plant cell, interrupting cytosolic metabolism and restricting Zn transport to sink tissues (Caldelas \& Weiss, 2017; Marschner, 2012). The formation of Zn complexes enhances Zn movement within the plant and helps to maintain the free $\mathrm{Zn}^{2+}$ concentration within the narrow, risk-free range for effective function (Kawakami \& Bhullar, 2018). In addition, dynamic changes of Zn speciation play a role in the efficiency of Zn translocation into the wheat grain (L. J. Palmer \& Stangoulis, 2018). A deeper understanding of the functions of $\mathrm{Zn}$ species requires careful investigation to increase bioavailable grain $\mathrm{Zn}$.

Zinc forms complexes with organic compounds having N-, S- and O- electron donors (AlvarezFernandez et al., 2014). These compounds include non-proteinogenic amino acids such as nicotianamine (NA) [2(S),3'(S),3"(S)-N-[N(3-amino-3-carboxypropyl)-3-amino-3-carboxypropyl] azetidine-2carboxylic acid], that are derived from NA including the mugineic acid family phytosiderophores (MA) and 2'-deoxy mugineic (DMA) amino acids (Clemens, Deinlein, Ahmadi, Horeth, \& Uraguchi, 2013; Sinclair \& Kramer, 2012), including histidine and cysteine (Cheah et al., 2019; Cheah, Kopittke, Scheckel, Noerpel, \& Bell, 2020), organic acid-carboxylates including malate and citrate (Haydon \& Cobbett, 2007), peptides (Clemens, 2019; Lemmens et al., 2019), as well as small proteins (metallothioneins) (Leszczyszyn \& Blindauer, 2010) (Figure 1).

Within separate compartments of the plant, different $\mathrm{Zn}$ complexes exist in varying proportions (Terzano et al., 2008). Among these Zn complexes, the ligands NA and DMA play significant roles in maintaining cytoplasmic $\mathrm{Zn}^{2+}$ concentrations within the desirable range. Genetic composition and/or the external environment are important in determining the $\mathrm{Zn}$ complexes present, their quantity, and in turn their effect on Zn use efficiency of the plant (Impa \& Johnson-Beebout, 2012; Moreira, Moraes, \& dos Reis, 2018). For instance, within a plant compartment, Zn speciation may respond to external stress factors such as low 
availability of soil Zn (Alvarez-Fernandez et al., 2014). Therefore, achieving Zn biofortification targets is likely to require deeper understanding of the compartmentalisation of $\mathrm{Zn}$ complexes and their environmental responses.

\section{1) Nicotianamine}

Nicotianamine is an intracellular metal chelator in all higher plants and the dominant Zn ligand in the cytosol, xylem and phloem, where it facilitates cellular trafficking of Zn (Rellan-Alvarez, Abadia, \& AlvarezFernandez, 2008). Nicotianamine complexes with divalent transition metal ions such as: $\mathrm{Zn}^{2+}, \mathrm{Fe}^{2+}, \mathrm{Fe}^{3+}$, $\mathrm{Mn}^{2+}, \mathrm{Ni}^{2+}$ and $\mathrm{Cu}^{2+}$ (Clemens et al., 2013; Nishiyama, Kato, Nagata, Yanagisawa, \& Yoneyama, 2012).

The nicotianamine synthase enzyme (NAS) regulates NA synthesis by converting S-adenosyl-L-methionine (SAM) to NA (Higuchi, Kanazawa, Nishizawa, Chino, \& Mori, 1994), and expression of NAS genes in roots of Triticum monococcum increased under deficient $\mathrm{Zn}$ or Fe conditions (Du et al., 2018). Zhao, Qu, Tong, and Zou (2019) suggesting that under higher nitrogen and low Zn supply, expression of TaNAS1 and TaNAS2 genes is upregulated and the consequent increase in NA biosynthesis facilitates increased Zn uptake and root to shoot transport in wheat. Studies based on rice under Fe starved conditions, revealed that over expression of OsNAS2 and OsNAS3 genes during grain filling increased NA, Zn and Fe concentrations in the roots, shoots and grain (Lee et al., 2009; S. P. Singh, Keller, Gruissem, \& Bhullar, 2017). In bread wheat, the higher expression of TaNAS genes resulted in increased biosynthesis of NA, which facilitates response to Fe deficiency (Bonneau, Baumann, Beasley, Li, \& Johnson, 2016). There is a major knowledge gap in understanding the functions of the NAS gene in relation to Zn use efficiency under environmental conditions, such as variable soil $\mathrm{Zn}$ and $\mathrm{pH}$.

\section{2)Chelating compounds derived from nicotianamine}

Zinc also chelates with compounds derived from NA, such as 2'-deoxy mugineic acid (DMA) and other mugineic acids (MAs) (Figure 1) that are commonly found in graminaceous plants (Diaz-Benito et al., 2018). To produce DMA, NA is converted to a 3"-keto acid by NA aminotransferase (NAAT), then to 2'deoxy-mugineic acid, and to other MAs produced by DMA synthase (Bashir et al., 2006; Bashir \& Nishizawa, 2006). Increased expression of TaNAAT2 gene in anther tissues, and TaNAAT1 in roots under Fe starved conditions, regulates DMA biosynthesis and maintains cellular Fe content at an appropriate level in wheat (Beasley, Bonneau, \& Johnson, 2017). Comparable studies are required under Zn deficiency to determine the temporal regulation of these genes.

Mugineic acid is a low molecular weight, non-proteinogenic amino acid having chelating properties. The mugineic acid family of phytosiderophores are the main compounds derived from NA in gramineaceous plants, including wheat (Cakmak, Gulut, Marschner, \& Graham, 1994). Zinc deficient plants produce phytosiderophores that are excreted into the rhizosphere, where they complex with $\mathrm{Zn}$ and increase its availability (Daneshbakhsh, Khoshgoftarmanesh, Shariatmadari, \& Cakmak, 2013; Hopkins, Whitney, Lamond, \& Jolley, 1998; Mitra, 2015). Therefore, it has been recognised that phytosiderophores are a promising target to improve the efficiency of Zn uptake in wheat.

\section{3.) THE CRUCIAL REGULATORY ROUTE FOR ZN BIOFORTIFICATION}

There is considerable uncertainty about the crucial regulatory routes of $\mathrm{Zn}$ uptake, transport, re-transport and grain loading in wheat, and filling these knowledge gaps is essential for developing cultivars having a

higher level of bioavailable grain $\mathrm{Zn}$. For $\mathrm{Zn}$ biofortification to succeed requires a greater understanding of $\mathrm{Zn}$ homeostasis, e.g. the facility to maintain cellular $\mathrm{Zn}$ levels sufficient to maintain function in the face of temporal fluctuations in the external supply (Caldelas \& Weiss, 2017; Clemens, Palmgren, \& Kramer, 2002). A strongly controlled network of $\mathrm{Zn}$ membrane transporters, regulators, $\mathrm{Zn}$ binding proteins and $\mathrm{Zn}$ speciation ensures that an adequate level of $\mathrm{Zn}$ reaches the sink tissues while maintaining a sufficient level of cellular Zn to maintain other regulatory functions (Kramer \& Clemens, 2005; Sinclair \& Kramer, 2012).

\section{1)Zinc uptake}


Plants have varied, complicated and highly regulated sensing and response mechanisms to control the uptake and translocation of micronutrients (Marschner, 2012). These mechanisms are governed by many genes (Xu et al., 2012). The majority of cereal cultivars that thrive in Zn deficient soils may take up larger quantities of Zn than their less successful counterparts (Graham, 1984; Ruel \& Bouis, 1998). Zinc ions in the soil solution are transported towards the roots by mass flow and diffusion (Marschner, 2012). Zinc concentration in the rhizosphere (soil-root interface) is important for the efficient influx of Zn into plant roots (Khoshgoftarmanesh, Afyuni, Norouzi, Ghiasi, \& Schulin, 2018). However, $\mathrm{Zn}^{2+}$ cannot passively enter the root cell membranes (Alberts et al., 2008) and wheat uses two strategies to take $\mathrm{Zn}^{2+}$ into the root system as described in the following.

In the first, the majority of $\mathrm{Zn}^{2+}$ enters into the root through the cell-plasma membrane, where it is taken up by an active, specific transport system driven by photosynthetic energy (Santa-Marı \& Cogliatti, 1998). The Zn/Fe-regulated transporter-like proteins (ZIPs) are proposed as the major transporter family (Colangelo \& Guerinot, 2006; Eide, 2005), which is highly expressed during Zn-deficiency (Pedas, Schjoerring, \& Husted, 2009; Tiong et al., 2015). With adequate nitrogen supply, expression of TaZIP3 and TaZIP7 is upregulated in roots of Zn deficient wheat plants, increasing Zn uptake and grain Zn (Nie et al., 2019).

The second uptake strategy operates under low Zn availability, when the wheat root releases phytosiderophores that complex Zn, e.g. Zn-MA, and the complex is taken up with the help of Zn transporter families (Cakmak et al., 1996). In the wheat root it remains unclear which individuals of the specific transporters families are responsible for the uptake of the Zn-MA complex. However, the yellow stripe like (YSL) transporter family, in particular TaYS1A, TaYS1B, TaYSL3, TaYSL5 and TaYSL6, are involved in the uptake of the Fe-MA complex by wheat from the soil solution (Kumar et al., 2019). In wheat, it is possible that the YSL transporter family also regulates soil Zn uptake in the form of Zn-MA complex and transports it as NA-Zn complex. Further, it is also possible that the Zn-MA complex dissociates near the root surface, buffering the free $\mathrm{Zn}^{2+}$ activity at a higher level than in the bulk phase, and that uptake is predominatly as $\mathrm{Zn}^{2+}$. The detail of this uptake mechanism still needs to be studied.

Once Zn has been taken up by the roots, radial transport moves it through a number of plant cell membranes: epidermis, cortex, endodermis and pericycle, before entering the vascular tissue (xylem or phloem). Radial $\mathrm{Zn}$ movement from the root epidermis to xylem and phloem is critical to avoid excessive accumulation in root cell vacuoles (Ricachenevsky, de Araujo Junior, Fett, \& Sperotto, 2018). To minimise excessive accumulation of Zn, plants have evolved a chelator-dependent Zn mobilization system within roots (Cakmak et al., 1996). Chelator composition varies between plant species and in wheat roots, DMA is the predominant ligand (Puschenreiter et al., 2017). Different Zn transporter families are involved in the radial movement of Zn from the root cortex to the vascular tissue. For example, in wheat, the ZIP family transporters (Evens, Buchner, Williams, \& Hawkesford, 2017), $\mathrm{P}_{1 \mathrm{~B}}$-ATPases, also known as heavy metal ATPases (HMAs) (Tan et al., 2013), and cation diffusion facilitator family transporters (CDFs), and metal tolerance proteins (MTPs) (Kolaj-Robin, Russell, Hayes, Pembroke, \& Soulimane, 2015) regulate Zn transport within the plants. On the other hand, under Fe deficiency, the YSL transporter family assists Fe uptake / transport within the wheat root system (Kumar et al., 2019). It is suggested that the YSL transporter family may also support Zn uptake / transport within wheat roots under Zn deficiency (Kumar et al., 2019). However, little is known about the relationship between $\mathrm{Zn}$ complexes and the function of $\mathrm{Zn}$ transporter families in wheat (Borrill et al., 2014).

\section{2) Zinc translocation, grain $\mathrm{Zn}$ loading and bioavailability}

\subsection{1) Xylem}

Long distance metal transport from root-to-shoot mainly occurs passively in the xylem with the transpiration stream (Page \& Feller, 2015; Sadeghzadeh, 2013). However, Zn loading and unloading from the xylem require energy and involve a number of active transporters (Sondergaard, Schulz, \& Palmgren, 2004). Information on the loading and unloading of $\mathrm{Zn}$ in the wheat xylem is not well-documented; nonetheless, based on 
model plants and other cereals, it is suggested that HMA, ZIP and YSL family transporters regulate xylem loading. It has also been suggested that ZIP family transporters play a role in xylem unloading (Borrill et al., 2014; Curie et al., 2009; C. M. Palmer \& Guerinot, 2009). Further, it may be relevant that the HMA family transporters, either OsHMA2, OsHMA4, or both, have been involved in root xylem loading in rice (Takahashi et al., 2012).

While $\mathrm{Zn}$ can move in the xylem as a free cation or as a complex, the acidic $\mathrm{pH}$ of xylem sap (5.5) favors $\mathrm{Zn}$ movement as free $\mathrm{Zn}^{2+}$ (Alves et al., 2004). Smaller quantities of $\mathrm{Zn}$ complexes have been reported within the xylem of other plant species. e.g. in rocket (Eruca vesicaria L. Cavalieri) and the Zn hyperaccumulator, Sedum alfredii , significant amounts of $\mathrm{Zn}$ are associated with citric acid (Lu et al., 2013; Terzano et al., 2008). In contrast, peas (Pisum sativum ) have large amounts of Zn associated with NA (Flis et al., 2016). When the xylem is alkaline in response to flooding, drought, nutrients, bicarbonate, light, daily rhythms, diseases and change of season (Wilkinson, Corlett, Oger, \& Davies, 1998), conditions are more favourable to $\mathrm{Zn}$ complexes. It is still not known whether $\mathrm{Zn}$ is transported via the wheat xylem as a free cation or as different $\mathrm{Zn}$ complexes, e.g. little is yet known about speciation-mediated cellular trafficking of $\mathrm{Zn}$ in the wheat xylem.

\subsection{2) Phloem}

Zinc transport in the phloem is an active process (Palmgren et al., 2008). Senescing leaves are the primary site of phloem loading during Zn remobilization (Distelfeld, Avni, \& Fischer, 2014). Once Zn is moved into the phloem, it can reach developing sinks such as grain, where it is in high demand. In wheat, the xylem is discontinuous at the base of each grain, whereas the phloem provides a continuous gateway for Zn movement into the developing grain. Therefore, efficient phloem loading and unloading are required to upload Zn into the wheat grain (Pearson \& Rengel, 1995).

Phloem sap is slightly alkaline ( $\mathrm{pH}$ 7.3-8.5) (Dinant, Bonnemain, Girousse, \& Kehr, 2010), and this is a major limitation on $\mathrm{Zn}^{2+}$ mobility (P. J. White \& Broadley, 2011). The formation of complexes prevents precipitation and off-target metal binding, facilitating effective long-distance $\mathrm{Zn}$ transport via the phloem (Sinclair \& Kramer, 2012). While, Zn-NA is the predominant Zn complex ( $\sim 54 \%$ ) (Harris, Sammons, \& Grabiak, 2012; L. J. Palmer et al., 2014), a Zn-cysteine complex is also reported in high quantities ( $41 \%$ ) within the wheat phloem (L. J. Palmer \& Stangoulis, 2018). Further, Zn transport in the phloem is more efficient than through the xylem due to the presence of range of Zn species (N. Gupta, Ram, \& Kumar, 2016). Taken together, these results suggest that increasing Zn speciation in the wheat phloem, particularly complexation with NA and carboxylic acids, enhances Zn translocation.

The movement of $\mathrm{Zn}$ complexes through the phloem is powered by several active transporter families that regulate Zn loading and unloading process (Yoneyama, Ishikawa, \& Fujimaki, 2015). Based on studies with barley, the YSL transporter family assists phloem transport of Zn-NA complexes (Tauris, Borg, Gregersen, \& Holm, 2009). On the other hand, the HMA family transporters located in the intercellular membranes, particularly the tonoplast and chloroplast membranes, appear to be involved in $\mathrm{Zn}$ remobilization by releasing Zn into the phloem from storage tissues in the mesophyll cell (Kim et al., 2009; Mikkelsen et al., 2012). It has also been demonstrated that Zn movement from xylem to phloem is mainly governed by ZIP family transporters (Borrill et al., 2014). Although, this process is not fully understood in wheat, it is likely that YSL and HMA transporter families regulate Zn movement into the phloem.

\section{3) Wheat Grain Zn loading}

The wheat grain can acquire Zn from two main sources during the grain filling, e.g. from storage tissues by remobilization and through the root system by direct uptake (D. Y. Liu, Liu, Zhang, Chen, \& Zou, 2019). The relative contribution of each process has long been debated (Stomph, Jiang, \& Struik, 2009; Waters, Uauy, Dubcovsky, \& Grusak, 2009). Zn uptake and remobilization into the grain is largely dependent on soil and plant factors, e.g. length of the grain-filling period, plant nitrogen status, and the availability of soil 
Zn and water post-anthesis (Kutman, Kutman, Ceylan, Ova, \& Cakmak, 2012; Pearson \& Rengel, 1994). When soil Zn levels are low (D. Y. Liu et al., 2019), or moisture limits uptake (Cakmak \& Kutman, 2018), grain $\mathrm{Zn}$ concentration depends more on remobilization from storage organs (Xue et al., 2012). In contrast, under sufficient Zn supply, de novo root uptake predominates (D. Y. Liu et al., 2019), and under super optimal Zn supply, remobilization is barely detectable (Waters et al., 2009). Therefore, maintaining soil Zn uptake during grain-filling could increase levels of grain $\mathrm{Zn}$; however, soil moisture is likely to constrain $\mathrm{Zn}$ uptake across most of the wheat cropping area of the world. Consequently, a greater understanding of $\mathrm{Zn}$ remobilization may provide greater opportunities to increase grain $\mathrm{Zn}$ content.

Remobilization of nutrients from senescing plant parts to the developing grain has been demonstrated with many plant species, including wheat (Uauy, Distelfeld, Fahima, Blechl, \& Dubcovsky, 2006). In many cereals, grain development and plant senescence co-occur; therefore, nutrient remobilization, senescence and grain filling are intertwined with large scale transcriptional changes at the whole plant level (Cantu et al., 2011; Gregersen \& Holm, 2007). During this stage, Zn remobilization into the grain occurs from multiple plant tissues including leaves, stems, peduncle, rachis and florets (Pearson \& Rengel, 1994; Sharma et al., 2017).

Zinc remobilization into the grain and/or direct translocation of newly taken-up Zn into the developing grain is also highly regulated by the GPC-B1 gene (grain protein content) also called NAM (no apical meristem) (Uauy et al., 2006; Waters et al., 2009). The highest level of GPC genes is expressed in the flag leaf during grain filling (Uauy et al., 2006), which supports hypothesis that GPC plays a key role in Zn remobilization. The wheat genome consists of three NAM genes, but most of the modern bread and durum wheat varieties have a non-functional allele of NAM-B1, perhaps, gene product could cause delayed senescence thus reduce the remobilization and then loading into wheat grain (Velu, Singh, et al., 2017). Recently, an Australian germplasm screening study identified varieties with a functional copy of the NAM gene (Yang et al., 2018). The NAM-B1 genes that belong to NAC transcription factor found in wild emmer wheat (Triticum turgidum L. var.dicoccoides ) have the ability to increase grain $\mathrm{Zn}, \mathrm{Fe}$ and protein content more that of modern wheat varieties (Cakmak et al., 2004; Uauy et al., 2006; Waters et al., 2009). These findings suggest that there are opportunities to use these varieties in wheat breeding programs as parental materials to increase grain $\mathrm{Zn}$ level. However, accelerated senescence caused by the same gene reduces the length of the grain filling period; therefore, the NAM-B1 gene may be a Damocles' Sword (Barneix, 2007). Fortunately, some wheat breeding lines have a positive correlation between the NAM-B1 gene and grain yield (Velu, Singh, et al., 2017). Though it is challenging to utilize only the positive aspects of the NAM-B1 gene, it remains a promising target for increased grain Zn. Information on other loci influencing grain Zn content is scarce. Therefore, identification of loci that are likely to be associated with higher grain $\mathrm{Zn}$, together with higher grain yields are essential to achieve biofortification targets.

Zinc is an essential functional element of photosystem II, and a large amount of $\mathrm{Zn}$ is located in the vacuole, which is a major Zn reservoir for the developing grain. Several members of ZIP, YSL, HMA and NRAMP are located in the plasma membrane, vacuole or chloroplast, and regulate the direction of Zn remobilization from the source tissues to the developing grain in rice and maize (Li et al., 2013; Mani \& Sankaranarayanan, 2018; Olsen et al., 2016; Sperotto et al., 2010). The functional role of each transporter family in the wheat chloroplast and tonoplast during grain filling is unclear; however, the HvHMA1 transporters facilitate the movement of $\mathrm{Zn}$ from the chloroplast during senescence in barley (Mikkelsen et al., 2012). As wheat, rice and barley are closely related, it is possible that the VIT and MTP transporter families are also involved in regulating vascular $\mathrm{Zn}$ transport. On the other hand, HMA transporters are likely to play a role in regulating $\mathrm{Zn}$ transport from the chloroplast in wheat.

Zinc stored in the leaf vacuole is usually complexed with ligands such as NA, malate, citrate, histidine, cysteine and PA (Sinclair \& Kramer, 2012). In the leaf vacuole of wheat, Zn is co-localized with phytate and citrate, which resist the Zn translocation process and may lead to the development of Zn toxicity at the point of foliar fertilizer application (Doolette et al., 2018). In Zn hyperaccumulator plants, the main Zn ligands are cysteine, histidine and malate, which may tightly regulate the storage, redistribution and detoxifying process within the plant (Lu et al., 2014; Terzano et al., 2008). It has been suggested that $\mathrm{Zn}$ 
remobilization can be improved by decreasing the less mobile Zn complexes in leaf vacuoles such as phytate and citrate.

Anatomical barriers are also responsible for inefficient Zn loading into the wheat grain (Palmgren et al., 2008). At the base of the pericarp, thick-walled vessel elements with no pathway via the lumina (modified tracheary elements) make the xylem discontinuous: a barrier for micronutrient translocation into the grain unique to wheat (Herren \& Feller, 1994; Wang, Specht, \& Horst, 2011; Zee \& O'Brien, 1970). Xylem discontinuity between the floral stalk and the pericarp adds an additional apoplastic barrier between the grain and stem. Therefore, additional transport steps such as xylem unloading, phloem loading and unloading are required in the wheat rachis or peduncle for $\mathrm{Zn}$ in the xylem to reach the developing grain (Herren \& Feller, 1994; Pearson, Rengel, Jenner, \& Graham, 1995) via the phloem (Wang et al., 2011; Zee \& O'Brien, 1970). Pearson et al. (1995) suggest that the majority of Zn enters into the phloem with the help of a xylem-to-phloem transport system operating in the rachis. Small amounts of $\mathrm{Zn}$ could also be transferred from the xylem sap into the phloem in the peduncle (Herren \& Feller, 1994). One approach to increase the efficiency of Zn loading into the wheat grain would be if $\mathrm{Zn}$ were translocated directly to the grain through the xylem and such a mechanism has been reported in rice (Zee, 1972). Identifying wheat mutants or wild relatives without these anatomical barriers could provide a major breakthrough in Zn biofortification.

Zinc loading into the endosperm of the wheat grain is the major bottleneck to increase Zn content in white flour. Zinc transported into the stem phloem of wheat enters the grain crease phloem where it transfers into the vascular bundle, and moves through the transfer cells of the nucellar projection into the endosperm cavity (Borg, Brinch-Pedersen, Tauris, \& Holm, 2009; Pearson, Rengel, Jenner, \& Graham, 1996). From there, $\mathrm{Zn}$ is taken up by cells of the modified aleurone layer before being transferred into the endosperm, embryo and aleurone layer. Consequently, a higher $\mathrm{Zn}$ concentration is present in the aleurone layer and embryo, but the endosperm contains relatively low amounts of $\mathrm{Zn}$. The highest $\mathrm{Zn}$ content was reported in modified aleurone cells adjoining the crease region (De Brier et al., 2016). It has been demonstrated that constitutive expression of OsNAS2 gene in the modified aleurone layer of wheat grain is well associated with $\mathrm{Zn}$ concentration in the crease region (Beasley et al., 2019). In many instances, Zn concentration increases in the crease region when $\mathrm{Zn}$ is externally supplied, but endosperm $\mathrm{Zn}$ concentration increases only at a marginal rate (Ajiboye et al., 2015; Stomph, Choi, \& Stangoulis, 2011). These findings clearly demonstrate tight physical and/or physiochemical control of Zn transfer from the crease region transfer cells to the inner endosperm. De Brier et al. (2016), suggesting that Zn transfer to the endosperm is inhibited and/or slowed at the transfer cell level. It is possible that the presence of specific Zn binding ligands in the transfer cell vacuole act as a crucial limiting factor for Zn transfer into the endosperm (Wang et al., 2011). Further, the presence of phytate globoids in the aleurone cells also restricts Zn mobility, causing lower Zn concentration in the endosperm (Ajiboye et al., 2015). On the other hand, in wheat endosperm, $\mathrm{Zn}$ is present as complexes with NA, DMA and S-containing peptides (Eagling et al., 2014; Persson et al., 2016; Xue et al., 2014). In rice, NA and DMA help to increase Zn content in the grain (Lee et al., 2011). In the embryo of wheat grain, higher levels of $\mathrm{Zn}$ is reported in the root and shoot primordium by making a complex with sulphur, probably thiol groups such as cysteine (De Brier et al., 2016).

Studies of foliar Zn application have suggested that Zn transfer to the inner endosperm from the rachis is relatively easy when $\mathrm{Zn}$ is applied during grain filling (Ajiboye et al., 2015). Under these conditions, 70-80\% of the grain $\mathrm{Zn}$ is complexed with phosphate (Zhang et al., 2018), and a smaller proportion of endosperm $\mathrm{Zn}$ is complexed with phytate (Velu et al., 2014). Therefore, most of the foliar applied Zn present in the wheat endosperm is bioavailable (Ajiboye et al., 2015). These findings suggest that strategies for Zn uptake into the grain may differ when it comes to soil and foliar applications, which may create new opportunities for Zn biofortification.

Transegenic approaches have been made to over express Zn transporters in wheat grains. Vatansever, Filiz, and Eroglu (2017) showed that overexpression of MTP transporters in the aleurone layer contributes to high level of $\mathrm{Zn}$ in wheat grain. Kumar et al. (2019) suggested that TaYSL20 is a key candidate gene regulating mineral distribution in the wheat grain. Moreover, higher expression of TaYSL3-2A, TaYSL12-2A, TaYSL6, 
and TaYSL15-3D are also reported in the seed coat and aleurone layer. The expression of these genes and grain $\mathrm{Zn}$ and Fe levels are well correlated across a number of wheat cultivars. However, in-depth knowledge is required to understand how Zn transporters are regulated in a site-specific manner and how they are associated with Zn localization in the wheat grain.

Detailed descriptions of the crease region and embryo are shown in Figure 2.

\section{4)Anti-nutritional factors controlling the bioavailability of grain $\mathrm{Zn}$}

The bioavailability of $\mathrm{Zn}$ and other micronutrients in the human diet is lowered by the low Zn levels in wheat flour, together with the anti-nutritional factors in plant-derived foods (Perera et al., 2018). Phytic acid [(myo-inositol-1,2,3,4,5,6-hexakisphosphate) and polyphenols (Schlemmer, Frolich, Prieto, \& Grases, 2009) are recognised as major determinants of the bioavailability of $\mathrm{Zn}$ and other essential micronutrients. Phytic acid, the main store of phosphorus in the grain, makes micronutrients less available for monogastric animals, including humans, due to its chelation characteristics (R. K. Gupta, Gangoliya, \& Singh, 2015). In general, PA is abundant in the aleurone layer and pericarp (2.0-5.3\%), while lesser amounts (1.1-3.9\%) have been recorded in the embryo (Kasim \& Edwards, 1998). Most of the micronutrients and macronutrients including $\mathrm{Zn}, \mathrm{Fe}, \mathrm{Ca}, \mathrm{Mg}$ and $\mathrm{K}$ in the aleurone layer complex with PA. Further, nutrient transfer is inhibited at the aleurone layer level, which lowers both Zn concentration and its bioavailability (Raboy, 2003; Schlemmer et al., 2009; Simpson \& Wise, 1990). Therefore, lowering the grain PA level is an indirect strategy to improve Zn concentration and its bioavailability in the wheat grain (Gregory et al., 2017).

Large genetic variations in grain PA levels occur among wheat cultivars (Shitre et al., 2015). This existing genetic variation could effectively be utilized to select wheat lines with less PA content for current breeding programs (Magallanes-Lopez et al., 2017). There are other opportunities to reduce PA content; for example, wheat lines with lpa1-type mutants have about $43 \%$ less PA in the grain (Guttieri, Bowen, Dorsch, Raboy, \& Souza, 2004). Moreover, lower PA concentrations could be achieved by genetically transforming the plant to produce greater amounts of phytase (Brinch-Pedersen, Madsen, Dionisio, \& Holm, 2017; BrinchPedersen, Olesen, Rasmussen, \& Holm, 2000), to release phosphate and mineral residues from phytate (Brinch-Pedersen, Sørensen, \& Holm, 2002). However, PA may play a role in signalling plant development and defence responses; therefore, careful consideration is needed (Sparvoli \& Cominelli, 2015).

Based on the cited studies, a schematic model of speciation-mediated $\mathrm{Zn}$ transport in the wheat plant is presented in Figure 3.

\section{4.) CAPITALIZING ON GENETIC DIVERSITY FOR Zn BIOFORTIFICATI- ON IN WHEAT}

A number of genetic traits can be used for enhancement of grain Zn concentration and its bioavailability. Genetic variation in wild relatives can be used to develop bread wheat, e.g. crossing hexaploid bread wheat with tetraploid durum has helped to increase grain Zn concentration. Further, wheat wild relatives Aegilops kotschyiand Aegilops tauschii also contain appreciably higher concentrations of grain Zn. Identifying and mapping molecular markers for quantitative trait loci (QTL) for grain Zn can be used to select for increased grain Zn concentration (Rawat et al., 2009; Tiwari et al., 2010). Inter-specific crosses can be made in wheat breeding programs and these traits can be easily captured using marker assisted selection (Rawat et al., 2009; Tiwari et al., 2010). However, for genetic biofortification to be quickly implemented, it is preferable to have high variability within adapted, high quality and high yielding bread wheat lines (Pascoalino et al., 2018). In this scenario, preference should be given to wheat genotypes that grow well in soils low in available Zn (Gomez-Coronado, Poblaciones, Almeida, \& Cakmak, 2016). However, this is a temporary solution as the soil $\mathrm{Zn}$ resource is finite.

Compared to many other agriculturally important cereals, wheat is a relatively difficult breeding target. The wheat genome is large and complex $(16,000 \mathrm{Mb})$, allohexaploid $(2 \mathrm{n}=6 \mathrm{x}=42)$ comprising AABBDD 
genomes, and exhibits a low transformation frequency, high proportion of repeat DNA and low regeneration after transformation (Bhalla, 2006; Sahrawat, Becker, Lütticke, \& Lörz, 2003). Amongst all this, knowledge gaps in the complex molecular pathways, transporters, genes, and speciation involved in $\mathrm{Zn}$ homeostasis are bottlenecks, which may limit the success of genetic biofortification. Therefore, a detailed understanding of the mechanisms of $\mathrm{Zn}$ uptake, translocation, remobilization, and grain loading will provide much needed information to fast-track genetic biofortification.

\section{5.) PRESENT KNOWLEDGE AND OPPORTUNITIES FOR FUTURE RESEARCH TO ACHIEVE WHE- AT BIOFORTIFICATION TARGETS}

Grain $\mathrm{Zn}$ concentration is strongly influenced by $\mathrm{Zn}$ translocation, remobilization and grain loading (Palmgren et al., 2008). Therefore, it is essential to select genetic traits with better Zn uptake together with efficient $\mathrm{Zn}$ translocation, remobilization and grain loading for wheat breeding to achieve $\mathrm{Zn}$ biofortification. Inefficient $\mathrm{Zn}$ loading into the grain, particularly to the endosperm, is a major bottleneck to improved $\mathrm{Zn}$ levels in wheat grain (Ajiboye et al., 2015). On the other hand, there are opportunities to enhance the transfer of $\mathrm{Zn}$ from source organs, e.g. roots, leaves, stem and peduncle, into the grain by selecting wheat cultivars having efficient remobilization (Pearson \& Rengel, 1994; Waters \& Sankaran, 2011). Moreover, considerable genetic variation has been detected in Zn use efficiency among wheat cultivars (Kalayci et al., 1999; Velu et al., 2011; Velu, Tutus, et al., 2017). These findings suggest that grain Zn concentration can be improved 3-5 fold if superior genetic traits are embedded during breeding.

NAM genes that are responsible for increased grain Zn content have already been mapped and major QTLs have been identified for this trait in wild emmer wheat (Triticum turgidum subsp. dicoccum ) (Joppa, Du, Hart, \& Hareland, 1997). These genes have now been cloned and have increased Zn, Fe and protein content by $12 \%, 18 \%$ and $38 \%$, respectively (Distelfeld et al., 2007; Uauy et al., 2006).Aegilops genes responsible for higher grain $\mathrm{Zn}$ and Fe content have also been transferred from wheat-Aegilops substitution lines into modern wheat cultivars to increase the grain Zn content (Sharma et al., 2018). A problem with all of these wild crosses is linkage drag and the need to reduce the size of the introduced chromosome segment to minimize the deleterious effect on wheat morphology, yield quality or disease resistance.

Increasing the total $\mathrm{Zn}$ content in wheat grain is not the only focus of wheat biofortification, as absorption in the human digestive tract depends on the presence of anti-nutritional factors, notably PA (Ciccolini et al., 2017). Enhancing bioavailability of $\mathrm{Zn}$ in the grain by lowering PA levels is another approach (Chugh \& Dhaliwal, 2013). The wheat genes responsible for PA biosynthesis and transport have been identified and can be manipulated to minimise PA biosynthesis (Sparvoli \& Cominelli, 2015). In addition, QTLs for PA have been identified in wheat and moved into breeding programmes to reduce PA levels in the grain (Raboy, Young, Dorsch, \& Cook, 2001). At present, grains with low PA content are being developed either through low-PA mutants produced by chemical, or irradiation-induced mutagenesis, or by transgenic Aspergillus niger (phy A ) phytase gene transformed into wheat (Ahn, Kim, Jo, Kim, \& Byun, 2004; Venegas et al., 2018). Combining two genes (lpa1-1 - low grain PA and Gpc-B1- grain protein content) has been shown to increase the grain Zn content while maintaining a higher grain yield (Venegas et al., 2018).

Development of genome editing techniques, such as clustered regularly interspaced short palindromic repeats (CRISPR)/ CRISPR-associated protein 9 (Cas9) allows for the production of transgene-free improved varieties. Wheat grains with higher endosperm Zn content, reduced PA level, increased endosperm NA and thicker aleurone cell layer can be engineered in future by targeting multiple genes in a pathway level via the CRISPR/Cas 9 technique and can be effectively adapted to improve micronutrient assimilation into the grain. A fundamental understanding of the molecular mechanisms involved in $\mathrm{Zn}$ homeostasis in the wheat plant, including the pathways for Zn uptake, transport, remobilization and grain Zn loading, will in the future, help to develop Zn biofortified wheat. 


\section{6.) CONCLUSIONS}

With traditional breeding approaches, the complexities of the wheat genome make it difficult to predict the rate of improvement. Nonetheless, modern wheat cultivars have greater Zn uptake, but Zn loading into the endosperm remains restricted due to biochemical limitations in the crease region. Zn bioavailability is also reduced as a result of increased accumulation of PA in the grain. However, these limitations are not common among old wheat progenitors. A deeper understanding of the cumulative gene effects that regulate specific functions of Zn uptake, transport, remobilization, grain loading, Zn speciation and synthesis of PA is important to increase the level of bioavailable grain Zn.

\section{ACKNOWLEDGEMENT}

This work was supported by the University of Southern Queensland, Australia. Elemental distribution of grain sections research was undertaken on the x-ray fluorescence microscopy (XFM) beamline at the Australian Synchrotron, part of ANSTO.

\section{CONFLICT OF INTEREST}

The authors declare that they have no conflict of interest.

\section{REFERENCES}

Ahn, H.-J., Kim, J.-H., Jo, C., Kim, M.-J., \& Byun, M.-W. (2004). Comparison of irradiated phytic acid and other antioxidants for antioxidant activity. Food Chemistry, 88 (2), 173-178. doi:10.1016/j.foodchem.2004.02.001

Ajiboye, B., Cakmak, I., Paterson, D., de Jonge, M. D., Howard, D. L., Stacey, S. P., . . McLaughlin, M. J. (2015). X-ray fluorescence microscopy of zinc localization in wheat grains biofortified through foliar zinc applications at different growth stages under field conditions. Plant and Soil, 392 (1-2), 357-370. doi:10.1007/s11104-015-2467-8

Alberts, B., Johnson, A., Lewis, J., Raff, M., Roberts, K., \& Walter, P. (2008). Molecular biology of the cell (5 ed.). Garland Science, New York.

Alloway, B. J. (2008). Zinc in soils and crop nutrition. In (2 $2^{\text {nd }}$ ed., pp. 14-54). International fertilizer Industry Association and International Zinc Association, Brussels, Belgium and Paris: IZA and IFA.

Alvarez-Fernandez, A., Diaz-Benito, P., Abadia, A., Lopez-Millan, A. F., \& Abadia, J. (2014). Metal species involved in long distance metal transport in plants. Frontiers in Plant Science, 5 , 1-20. doi:10.3389/fpls.2014.00105

Alves, G., Ameglio, T., Guilliot, A., Fleurat-Lessard, P., Lacointe, A., Sakr, S., . . Julien, J.-L. (2004). Winter variation in xylem sap $\mathrm{pH}$ of walnut trees: involvement of plasma membrane $\mathrm{H}^{+}$-ATPase of vesselassociated cells. Tree Physiology, 24 (1), 99-105.

Barber, S. A. (1995). Soil nutrient bioavailability: a mechanistic approach. $2^{\text {nd }}$ ed. In Chemistry of soil nutrient association (pp. 9-49). New York: John Wiley \& Sons.

Barneix, A. J. (2007). Physiology and biochemistry of source-regulated protein accumulation in the wheat grain. Journal of Plant Physiology, 164 (5), 581-590. doi:10.1016/j.jplph.2006.03.009

Bashir, K., Inoue, H., Nagasaka, S., Takahashi, M., Nakanishi, H., Mori, S., \& Nishizawa, N. K. (2006). Cloning and characterization of deoxymugineic acid synthase genes from graminaceous plants. Journal of Biological Chemistry, 281 (43), 32395-32402. doi:10.1074/jbc.M604133200 
Bashir, K., \& Nishizawa, N. K. (2006). Deoxymugineic acid synthase: a gene important for Fe-acquisition and homeostasis. Plant Signaling and Behavior, 1 (6), 290-292.

Beasley, J. T., Bonneau, J. P., \& Johnson, A. A. T. (2017). Characterisation of the nicotianamine aminotransferase and deoxymugineic acid synthase genes essential to Strategy II iron uptake in bread wheat (Triticum aestivum L.). PLoS One, 12 (5), 1-18. doi:10.1371/journal.pone.0177061

Beasley, J. T., Bonneau, J. P., Sanchez-Palacios, J. T., Moreno-Moyano, L. T., Callahan, D. L., Tako, E., . .. Johnson, A. A. T. (2019). Metabolic engineering of bread wheat improves grain iron concentration and bioavailability. Plant Biotechnology Journal, 17 (8), 1514-1526. doi:10.1111/pbi.13074

Bhalla, P. L. (2006). Genetic engineering of wheat-current challenges and opportunities. Trends in Biotechnology, 24 (7), 305-311. doi:10.1016/j.tibtech.2006.04.008

Bilgrami, S. S., Houshmand, S., Kadivar, M., Fakheri, B., Zandi, P., Shariati, V., . . Możdżeń, K. (2017). Phytic acid, iron and zinc content in wheat ploidy levels and amphiploids: the impact of genotype and planting seasons. Archives of Agronomy and Soil Science, 64 (3), 331-346. doi:10.1080/03650340.2017.1352085

Bonneau, J., Baumann, U., Beasley, J., Li, Y., \& Johnson, A. A. (2016). Identification and molecular characterization of the nicotianamine synthase gene family in bread wheat. Plant Biotechnology Journal, 14 (12), 2228-2239. doi:10.1111/pbi.12577

Borg, S., Brinch-Pedersen, H., Tauris, B., \& Holm, P. B. (2009). Iron transport, deposition and bioavailability in the wheat and barley grain. Plant and Soil, 325 (1-2), 15-24. doi:10.1007/s11104-009-0046-6

Borrill, P., Connorton, J. M., Balk, J., Miller, A. J., Sanders, D., \& Uauy, C. (2014). Biofortification of wheat grain with iron and zinc: integrating novel genomic resources and knowledge from model crops.Frontiers in Plant Science, 5 (53), 1-8. doi:10.3389/fpls.2014.00053

Bouis, H. E., \& Saltzman, A. (2017). Improving nutrition through biofortification: A review of evidence from HarvestPlus, 2003 through 2016. Global Food Security, 12 , 49-58. doi:10.1016/j.gfs.2017.01.009

Brinch-Pedersen, H., Madsen, C. K., Dionisio, G., \& Holm, P. B. (2017). High expression cereal phytase gene. In: Google Patents.

Brinch-Pedersen, H., Olesen, A., Rasmussen, S. K., \& Holm, P. B. (2000). Generation of transgenic wheat (Triticum aestivum L.) for constitutive accumulation of an Aspergillus phytase. Molecular Breeding, 6 (2), 195-206.

Brinch-Pedersen, H., Sørensen, L. D., \& Holm, P. B. (2002). Engineering crop plants: getting a handle on phosphate. Trends in Plant Science, 7 (3), 118-125.

Cakmak, I. (2008). Enrichment of cereal grains with zinc: Agronomic or genetic biofortification? Plant and Soil, 302 , 1-17. doi:10.1007/s11104-007-9466-3

Cakmak, I., Gulut, K. Y., Marschner, H., \& Graham, R. D. (1994). Effect of zinc and iron deficiency on phytosiderophore release in wheat genotypes differing in zinc efficiency. Journal of Plant Nutrition, 17 (1), $1-17$.

Cakmak, I., \& Kutman, U. B. (2018). Agronomic biofortification of cereals with zinc: a review. European Journal of Soil Science, 69 (1), 172-180. doi:10.1111/ejss.12437

Cakmak, I., Pfeiffer, W. H., \& McClafferty, B. (2010). Biofortification of durum wheat with zinc and iron. Cereal Chemistry, 87 (1), 10-20.

Cakmak, I., Sari, N., Marschner, H., Ekiz, H., Kalayci, M., Yilmaz, A., \& Braun, H. J. (1996). Phytosiderophore release in bread and durum wheat genotypes differing in zinc efficiency. Plant and Soil, 180 , 183-189. 
Cakmak, I., Torun, A., Millet, E., Feldman, M., Fahima, T., Korol, A., . . Özkan, H. (2004). Triticum dicoccoides : An important genetic resource for increasing zinc and iron concentration in modern cultivated wheat. Soil Science and Plant Nutrition, 50 (7), 1047-1054. doi:10.1080/00380768.2004.10408573

Caldelas, C., \& Weiss, D. J. (2017). Zinc homeostasis and isotopic fractionation in plants: a review. Plant and Soil, 411 (1-2), 17-46. doi:10.1007/s11104-016-3146-0

Cantu, D., Pearce, S. P., Distelfeld, A., Christiansen, M. W., Uauy, C., Akhunov, E., . . Dubcovsky, J. (2011). Effect of the down-regulation of the high Grain Protein Content (GPC) genes on the wheat transcriptome during monocarpic senescence. BMC Genomics, 12 , 1-17. doi:10.1186/1471-2164-12-492

Cheah, Z. X., Kopittke, P. M., Harper, S. M., Meyer, G., O'Hare, T. J., \& Bell, M. J. (2019). Speciation and accumulation of $\mathrm{Zn}$ in sweetcorn kernels for genetic and agronomic biofortification programs. Planta, 250 (1), 219-227. doi:10.1007/s00425-019-03162-x

Cheah, Z. X., Kopittke, P. M., Scheckel, K. G., Noerpel, M. R., \& Bell, M. J. (2020). Comparison of Zn accumulation and speciation in kernels of sweetcorn and maize differing in maturity. Annals of Botany, 125 (1), 185-193.

Chugh, V., \& Dhaliwal, H. S. (2013). Biofortification of staple crops. In Agricultural Sustainability (pp. 177-196): Elsevier.

Ciccolini, V., Pellegrino, E., Coccina, A., Fiaschi, A. I., Cerretani, D., Sgherri, C., . . . Ercoli, L. (2017). Biofortification with iron and zinc improves nutritional and nutraceutical properties of common wheat flour and bread. Journal of Agricultural and Food Chemistry, 65 (27), 5443-5452. doi:10.1021/acs.jafc.7b01176

Clemens, S. (2019). Metal ligands in micronutrient acquisition and homeostasis. Plant, Cell $\mathscr{E}$ Environment, 42 (10), 2902-2912. doi:10.1111/pce.13627

Clemens, S., Deinlein, U., Ahmadi, H., Horeth, S., \& Uraguchi, S. (2013). Nicotianamine is a major player in plant Zn homeostasis.Biometals, 26 (4), 623-632. doi:10.1007/s10534-013-9643-1

Clemens, S., Palmgren, M. G., \& Krämer, U. (2002). A long way ahead: understanding and engineering plant metal accumulation. Trends in Plant Science, 7 (7), 309-315.

Colangelo, E. P., \& Guerinot, M. L. (2006). Put the metal to the petal: metal uptake and transport throughout plants. Current Opinion in Plant Biology, 9 (3), 322-330. doi:10.1016/j.pbi.2006.03.015

Cu, S. T., Guild, G., Nicolson, A., Velu, G., Singh, R., \& Stangoulis, J. (2020). Genetic dissection of zinc, iron, copper, manganese and phosphorus in wheat (Triticum aestivum L.) grain and rachis at two developmental stages. Plant Science, 291, 110338.

Curie, C., Cassin, G., Couch, D., Divol, F., Higuchi, K., Le Jean, M., . . Mari, S. (2009). Metal movement within the plant: contribution of nicotianamine and yellow stripe 1-like transporters. Annals of Botany, 103 (1), 1-11. doi:10.1093/aob/men207

Daneshbakhsh, B., Khoshgoftarmanesh, A. H., Shariatmadari, H., \& Cakmak, I. (2013). Phytosiderophore release by wheat genotypes differing in zinc deficiency tolerance grown with $\mathrm{Zn}$-free nutrient solution as affected by salinity. Journal of Plant Physiology, 170 (1), 41-46. doi:10.1016/j.jplph.2012.08.016

De Brier, N., Gomand, S. V., Donner, E., Paterson, D., Smolders, E., Delcour, J. A., \& Lombi, E. (2016). Element distribution and iron speciation in mature wheat grains (Triticum aestivum L.) using synchrotron X-ray fluorescence microscopy mapping and X-ray absorption near-edge structure (XANES) imaging. Plant, Cell Eै Environment, 39 (8), 1835-1847. doi:10.1111/pce.12749

De Steur, H., Demont, M., Gellynck, X., \& Stein, A. J. (2017). The social and economic impact of biofortification through genetic modification. Current Opinion in Biotechnology, 44 , 161-168. doi:10.1016/j.copbio.2017.01.012 
De Valença, A. W., Bake, A., Brouwer, I. D., \& Giller, K. E. (2017). Agronomic biofortification of crops to fight hidden hunger in sub-Saharan Africa. Global Food Security, 12 , 8-14. doi:10.1016/j.gfs.2016.12.001

Dhaliwal, S. S., Ram, H., Shukla, A. K., \& Mavi, G. S. (2019). Zinc biofortification of bread wheat, triticale, and durum wheat cultivars by foliar zinc fertilization. Journal of Plant Nutrition, 42 (8), 813-822. doi:10.1080/01904167.2019.1584218

Díaz-Benito, P., Banakar, R., Rodríguez-Menéndez, S., Capell, T., Pereiro, R., Christou, P., . . . Álvarez-Fernández, A. (2018). Iron and zinc in the embryo and endosperm of rice (Oryza sativa L.) seeds in contrasting 2'-Deoxymugineic acid/Nicotianamine scenarios.Frontiers in Plant Science, 9 , 1-17. doi:10.3389/fpls.2018.01190

Dinant, S., Bonnemain, J. L., Girousse, C., \& Kehr, J. (2010). Phloem sap intricacy and interplay with aphid feeding. Comptes Rendus Biologies, 333 (6-7), 504-515. doi:10.1016/j.crvi.2010.03.008

Distelfeld, A., Avni, R., \& Fischer, A. M. (2014). Senescence, nutrient remobilization, and yield in wheat and barley. Journal of Experimental Botany, 65 (14), 3783-3798. doi:10.1093/jxb/ert477

Distelfeld, A., Cakmak, I., Peleg, Z., Ozturk, L., Yazici, A. M., Budak, H., . . . Fahima, T. (2007). Multiple QTL-effects of wheat Gpc-B1 locus on grain protein and micronutrient concentrations. Physiologia Plantarum, 129 (3), 635-643. doi:10.1111/j.1399-3054.2006.00841.x

Doolette, C. L., Read, T. L., Li, C., Scheckel, K. G., Donner, E., Kopittke, P. M., . . . Lombi, E. (2018). Foliar application of zinc sulfate and zinc EDTA to wheat leaves: differences in mobility, distribution and speciation. Journal of Experimental Botany, 69 (18), 4469-4481. doi:10.1093/jxb/ery236

Du, X., Wang, H., He, J., Zhu, B., Guo, J., Hou, W., . . . Zhang, X. (2018). Identification of nicotianamine synthase genes in Triticum monococcum and their expression under different Fe and Zn concentrations. Gene, 672, 1-7. doi:10.1016/j.gene.2018.06.015

Eagling, T., Neal, A. L., McGrath, S. P., Fairweather-Tait, S., Shewry, P. R., \& Zhao, F. J. (2014). Distribution and speciation of iron and zinc in grain of two wheat genotypes. Journal of Agricultural and Food Chemistry, 62 (3), 708-716. doi:10.1021/jf403331p

Eide, D. J. (2005). The ZIP family of zinc transporters. In S. Iuchi \& N. Kuldell (Eds.), Zinc Finger Proteins: From Atomic Contact to Cellular Function (pp. 261-264): Landes Bioscience/Eurekah.com and Kluwer Academic/Plenum Publishers. .

Evens, N. P., Buchner, P., Williams, L. E., \& Hawkesford, M. J. (2017). The role of ZIP transporters and group F bZIP transcription factors in the Zn-deficiency response of wheat (Triticum aestivum ). The Plant Journal, 92 (2), 291-304. doi:10.1111/tpj.13655

Fan, M. S., Zhao, F. J., Fairweather-Tait, S. J., Poulton, P. R., Dunham, S. J., \& McGrath, S. P. (2008). Evidence of decreasing mineral density in wheat grain over the last 160 years. Journal of Trace Elements in Medicine and Biology, 22 (4), 315-324. doi:10.1016/j.jtemb.2008.07.002

FAO. (2019). Food and agriculture organization Retrieved from http://www.fao.org/news/archive/news-bydate $/ 2019 / \mathrm{en} /$

Fernando, N., Panozzo, J., Tausz, M., Norton, R. M., Fitzgerald, G. J., Myers, S., . . . Seneweera, S. (2014). Intra-specific variation of wheat grain quality in response to elevated $\left[\mathrm{CO}_{2}\right]$ at two sowing times under rain-fed and irrigation treatments. Journal of Cereal Science, 59 (2), 137-144. doi:10.1016/j.jcs.2013.12.002

Fernando, N., Panozzo, J., Tausz, M., Norton, R. M., Fitzgerald, G. J., Myers, S., . . . Seneweera, S. (2012). Wheat grain quality under increasing atmospheric CO2 concentrations in a semi-arid cropping system. Journal of Cereal Science, 56 (3), 684-690. doi:10.1016/j.jcs.2012.07.010

Fernando, N., Panozzo, J., Tausz, M., Norton, R. M., Neumann, N., Fitzgerald, G. J., \& Seneweera, S. (2014). Elevated $\mathrm{CO}_{2}$ alters grain quality of two bread wheat cultivars grown under different environmental 
conditions. Agriculture, Ecosystems \& Environment, 185 , 24-33. doi:10.1016/j.agee.2013.11.023

Flis, P., Ouerdane, L., Grillet, L., Curie, C., Mari, S., \& Lobinski, R. (2016). Inventory of metal complexes circulating in plant fluids: a reliable method based on HPLC coupled with dual elemental and high-resolution molecular mass spectrometric detection. New Phytologist, 211 (3), 1129-1141. doi:10.1111/nph.13964

Garcia-Oliveira, A. L., Chander, S., Ortiz, R., Menkir, A., \& Gedil, M. (2018). Genetic basis and breeding perspectives of grain iron and zinc enrichment in cereals. Frontiers in Plant Science, 9 , 1-13. doi:10.3389/fpls.2018.00937

Giri, C. C., \& Praveena, M. (2015). In vitro regeneration, somatic hybridization and genetic transformation studies: an appraisal on biotechnological interventions in grasses. Plant Cell, Tissue and Organ Culture, 120 (3), 843-860. doi:10.1007/s11240-014-0653-7

Glahn, R., Tako, E., Hart, J., Haas, J., Lung'aho, M., \& Beebe, S. (2017). Iron bioavailability studies of the first generation of iron-biofortified beans released in Rwanda. Nutrients, 9 (7), 1-11. doi:10.3390/nu9070787

Gomez-Coronado, F., Poblaciones, M. J., Almeida, A. S., \& Cakmak, I. (2016). Zinc (Zn) concentration of bread wheat grown under Mediterranean conditions as affected by genotype and soil/foliar Zn application.Plant and Soil, 401 (1-2), 331-346. doi:10.1007/s11104-015-2758-0

Graham, R. D. (1984). Breeding for nutritional characteristics in cereals. Advances in Plant Nutrition, 1 , 57-102.

Gregersen, P. L., \& Holm, P. B. (2007). Transcriptome analysis of senescence in the flag leaf of wheat (Triticum aestivum L.).Plant Biotechnology Journal, 5 (1), 192-206. doi:10.1111/j.1467-7652.2006.00232.x

Gregory, P. J., Wahbi, A., Adu-Gyamfi, J., Heiling, M., Gruber, R., Joy, E. J. M., \& Broadley, M. R. (2017). Approaches to reduce zinc and iron deficits in food systems. Global Food Security, 15 , 1-10. doi:10.1016/j.gfs.2017.03.003

Gruter, R., Meister, A., Schulin, R., \& Tandy, S. (2018). Green manure effects on zinc and cadmium accumulation in wheat grains (Triticum aestivum L.) on high and low zinc soils. Plant and Soil, 422 (1-2), 437-453. doi:10.1007/s11104-017-3486-4

Gupta, N., Ram, H., \& Kumar, B. (2016). Mechanism of zinc absorption in plants: uptake, transport, translocation and accumulation. Reviews in Environmental Science and Biotechnology, 15 (1), 89-109. doi:10.1007/s11157-016-9390-1

Gupta, R. K., Gangoliya, S. S., \& Singh, N. K. (2015). Reduction of phytic acid and enhancement of bioavailable micronutrients in food grains. Journal of Food Science and Technology, 52 (2), 676-684. doi:10.1007/s13197-013-0978-y

Guttieri, M., Bowen, D., Dorsch, J. A., Raboy, V., \& Souza, E. (2004). Identification and characterization of a low phytic acid wheat.Crop Science, 44 , 418-414.

Hao, Y., Velu, G., Pena, R. J., Singh, S., \& Singh, R. P. (2014). Genetic loci associated with high grain zinc concentration and pleiotropic effect on kernel weight in wheat (Triticum aestivumL.). Molecular Breeding, 34 (4), 1893-1902. doi:10.1007/s11032-014-0147-7

Harris, W. R., Sammons, R. D., \& Grabiak, R. C. (2012). A speciation model of essential trace metal ions in phloem. Journal of Inorganic Biochemistry, 116 , 140-150. doi:10.1016/j.jinorgbio.2012.07.011

HarvestPlus. (2019). Biofortification. Retrieved from https://www.harvestplus.org/

Haydon, M. J., \& Cobbett, C. S. (2007). Transporters of ligands for essential metal ions in plants. New Phytologist, 174 (3), 499-506. doi:10.1111/j.1469-8137.2007.02051.x 
Henderson, K. N., Tye-Din, J. A., Reid, H. H., Chen, Z., Borg, N. A., Beissbarth, T., . . . Anderson, R. P. (2007). A structural and immunological basis for the role of human leukocyte antigen DQ8 in celiac disease. Immunity, 27 (1), 23-34. doi:10.1016/j.immuni.2007.05.015

Herren, T., \& Feller, U. (1994). Transfer of zinc from xylem to phloem in the peduncle of wheat. Journal of Plant Nutrition, 17 (9), 1587-1598.

Higuchi, K., Kanazawa, K., Nishizawa, N. K., Chino, M., \& Mori, S. (1994). Purification and characterization of nicotianamine synthases from Fe-deficient barley roots. Plant and Soil, 165 (2), 173-179.

Hopkins, B. G., Whitney, D. A., Lamond, R. E., \& Jolley, V. D. (1998). Phytosiderophore release by Sorghum, wheat, and corn under zinc deficiency. Journal of Plant Nutrition, 21 (12), 2623-2637. doi:10.1080/01904169809365593

Impa, S. M., \& Johnson-Beebout, S. E. (2012). Mitigating zinc deficiency and achieving high grain Zn in rice through integration of soil chemistry and plant physiology research. Plant and Soil, 361 (1-2), 3-41. doi:10.1007/s11104-012-1315-3

Joppa, L. R., Du, C., Hart, G. E., \& Hareland, G. A. (1997). Mapping gene(s) for grain protein in tetraploid wheat (Triticum turgidumL.) using a population of recombinant inbred chromosome lines.Crop Science, 37 , 1586-1589.

Kalayci, M., Torun, B., Eker, S., Aydin, M., Ozturk , L., \& Cakmak, I. (1999). Grain yield, zinc efficiency and zinc concentration of wheat cultivars grown in a zinc-defcient calcareous soil in field and greenhouse. Field Crops Research, 63 , 87-89.

Kasim, A. B., \& Edwards, H. M. (1998). The analysis for inositol phosphate forms in feed ingredients. Journal of the Science of Food and Agriculture, 76 , 1-9.

Kaur, N., Kaur, H., \& Mavi, G. S. (2020). Assessment of nutritional and quality traits in biofortified bread wheat genotypes. Food Chemistry, 302 , 125342. doi:10.1016/j.foodchem.2019.125342

Kawakami, Y., \& Bhullar, N. K. (2018). Molecular processes in iron and zinc homeostasis and their modulation for biofortification in rice.Journal of Integrative Plant Biology, 60 (12), 1181-1198. doi:10.1111/jipb.12751

Khoshgoftarmanesh, A. H., Afyuni, M., Norouzi, M., Ghiasi, S., \& Schulin, R. (2018). Fractionation and bioavailability of zinc $(\mathrm{Zn})$ in the rhizosphere of two wheat cultivars with different $\mathrm{Zn}$ deficiency tolerance. Geoderma, 309 , 1-6. doi:10.1016/j.geoderma.2017.08.019

Kim, Y. Y., Choi, H., Segami, S., Cho, H. T., Martinoia, E., Maeshima, M., \& Lee, Y. (2009). AtHMA1 contributes to the detoxification of excess $\mathrm{Zn}(\mathrm{II})$ in Arabidopsis. The Plant Journal, 58 (5), 737-753. doi:10.1111/j.1365-313X.2009.03818.x

Kolaj-Robin, O., Russell, D., Hayes, K. A., Pembroke, J. T., \& Soulimane, T. (2015). Cation Diffusion Facilitator family: Structure and function. FEBS Letters, 589 (12), 1283-1295. doi:10.1016/j.febslet.2015.04.007

Kramer, U., \& Clemens, S. (2005). Functions and homeostasis of zinc, copper, and nickel in plants. In Molecular biology of metal homeostasis and detoxification (pp. 215-271): Springer.

Kumar, A., Kaur, G., Goel, P., Bhati, K. K., Kaur, M., Shukla, V., \& Pandey, A. K. (2019). Genomewide analysis of oligopeptide transporters and detailed characterization of yellow stripe transporter genes in hexaploid wheat. Functional and Integrative Genomics, 19 (1), 75-90. doi:10.1007/s10142-018-0629-5

Kutman, U. B., Kutman, B. Y., Ceylan, Y., Ova, E. A., \& Cakmak, I. (2012). Contributions of root uptake and remobilization to grain zinc accumulation in wheat depending on post-anthesis zinc availability and nitrogen nutrition. Plant and Soil, 361 (1-2), 177-187. doi:10.1007/s11104-012-1300-x 
Lee, S., Jeon, U. S., Lee, S. J., Kim, Y. K., Persson, D. P., Husted, S., . . . Nishizawa, N. K. (2009). Iron fortification of rice seeds through activation of the nicotianamine synthase gene. Proceedings of the National Academy of Sciences, 106 (51), 22014-22019.

Lee, S., Persson, D. P., Hansen, T. H., Husted, S., Schjoerring, J. K., Kim, Y. S., . . . An, G. (2011). Bioavailable zinc in rice seeds is increased by activation tagging of nicotianamine synthase. Plant Biotechnology Journal, 9 (8), 865-873. doi:10.1111/j.1467-7652.2011.00606.x

Lemmens, E., De Brier, N., Spiers, K. M., Garrevoet, J., Falkenberg, G., Smolders, E., \& Delcour, J. A. (2019). Steeping and germination of wheat (Triticum aestivum L.). II. Changes in spatial distribution and speciation of iron and zinc elements using pearling, synchrotron X-ray fluorescence microscopy mapping and X-ray absorption near-edge structure imaging. Journal of Cereal Science, 90 , 1-10. doi:10.1016/j.jcs.2019.102843

Leszczyszyn, O. I., \& Blindauer, C. A. (2010). Zinc transfer from the embryo-specific metallothionein EC from wheat: a case study.Physical Chemistry Chemical Physics, 12 (41), 13408-13418.

Li, S., Zhou, X., Huang, Y., Zhu, L., Zhang, S., Zhao, Y., . . . Chen, R. (2013). Identification and characterization of the zinc-regulated transporters, iron-regulated transporter-like protein (ZIP) gene family in maize. Plant Biology, 13 (114), 1-14.

Liu, D. Y., Liu, Y. M., Zhang, W., Chen, X. P., \& Zou, C. Q. (2019). Zinc uptake, translocation, and remobilization in winter wheat as affected by soil application of Zn fertilizer. Frontiers in Plant Science, 10 , 426. doi:10.3389/fpls.2019.00426

Liu, J., Wu, X., Yao, X., Yu, R., Larkin, P. J., \& Liu, C. M. (2018). Mutations in the DNA demethylase OsROS1 result in a thickened aleurone and improved nutritional value in rice grains. Proceedings of the National Academy of Sciences of the United States of America, 115 (44), 11327-11332. doi:10.1073/pnas.1806304115

Lu, L., Liao, X., Labavitch, J., Yang, X., Nelson, E., Du, Y., . . . Tian, S. (2014). Speciation and localization of $\mathrm{Zn}$ in the hyperaccumulator Sedum alfredii by extended X-ray absorption fine structure and micro-X-ray fluorescence. Plant Physiology and Biochemistry, 84 , 224-232. doi:10.1016/j.plaphy.2014.10.004

Lu, L., Tian, S., Zhang, J., Yang, X., Labavitch, J. M., Webb, S. M., . . . Brown, P. H. (2013). Efficient xylem transport and phloem remobilization of $\mathrm{Zn}$ in the hyperaccumulator plant species Sedum alfredii . New Phytologist, 198 (3), 721-731. doi:10.1111/nph.12168

Magallanes-Lopez, A. M., Hernandez-Espinosa, N., Velu, G., Posadas-Romano, G., Ordonez-Villegas, V. M. G., Crossa, J., . . . Guzman, C. (2017). Variability in iron, zinc and phytic acid content in a worldwide collection of commercial durum wheat cultivars and the effect of reduced irrigation on these traits. Food Chemistry, 237 , 499-505. doi:10.1016/j.foodchem.2017.05.110

Mani, A., \& Sankaranarayanan, K. (2018). In silico analysis of Natural Resistance-Associated Macrophage Protein (NRAMP) family of transporters in rice. The Protein Journal, 37 (3), 237-247. doi:10.1007/s10930018-9773-y

Marschner, H. (2012). Mineral Nutrition of Higher Plants (M. P. Ed. 3 ed.): Academic Press.

Maxfield, L., \& Crane, J. S. (2019). Zinc Deficiency. In StatPearls [Internet]: StatPearls Publishing. Retrieved from https://www.ncbi.nlm.nih.gov/books/NBK493231/.

McClung, J. P. (2019). Iron, Zinc, and Physical Performance.Biological Trace Element Research, 188 (1), 135-139. doi:10.1007/s12011-018-1479-7

Meenakshi, J. V., Johnson, N. L., Manyong, V. M., DeGroote, H., Javelosa, J., Yanggen, D. R., . . . Meng, E. (2010). How cost-effective is biofortification in combating micronutrient malnutrition? An ex ante assessment. World Development, 38 (1), 64-75. doi:10.1016/j.worlddev.2009.03.014 
Mikkelsen, M. D., Pedas, P., Schiller, M., Vincze, E., Mills, R. F., Borg, S., . . . Palmgren, M. G. (2012). Barley HvHMA1 is a heavy metal pump involved in mobilizing organellar $\mathrm{Zn}$ and $\mathrm{Cu}$ and plays a role in metal loading into grains. PLoS One, 7 (11), 1-13. doi:10.1371/journal.pone.0049027

Mitra, G. N. (2015). Zinc (Zn) Uptake. In Regulation of Nutrient Uptake by Plants (pp. 127-133): Springer.

Moreira, A., Moraes, L. A. C., \& dos Reis, A. R. (2018). The molecular genetics of zinc uptake and utilization efficiency in crop plants. InPlant Micronutrient Use Efficiency (pp. 87-108): Elsevier.

Murphy, K. M., Reeves, P. G., \& Jones, S. S. (2008). Relationship between yield and mineral nutrient concentrations in historical and modern spring wheat cultivars. Euphytica, 163 (3), 381-390. doi:10.1007/s10681008-9681-x

Nie, Z., Zhao, P., Shi, H., Wang, Y., Qin, S., \& Liu, H. (2019). Nitrogen supply enhances zinc uptake and root-to-shoot translocation via up-regulating the expression of TaZIP3 and TaZIP7 in winter wheat (Triticum aestivum ). Plant and Soil, 44 , 501-517. doi:10.1007/s11104-019-04295-4

Nishiyama, R., Kato, M., Nagata, S., Yanagisawa, S., \& Yoneyama, T. (2012). Identification of ZnNicotianamine and Fe-2'-Deoxymugineic acid in the phloem sap from rice plants (Oryza sativa L.). Plant Cell Physiology, 53 (2), 381-390. doi:10.1093/pcp/pcr188

Olsen, L. I., Hansen, T. H., Larue, C., Osterberg, J. T., Hoffmann, R. D., Liesche, J., . . . Palmgren, M. (2016). Mother-plant-mediated pumping of zinc into the developing seed. Nature Plants, 2 (5), 1-6. doi:10.1038/nplants.2016.36

Ozturk, L., Yazici, M. A., Yucel, C., Torun, A., Cekic, C., Bagci, A., . . . Cakmak, I. (2006). Concentration and localization of zinc during seed development and germination in wheat. Physiologia Plantarum, 128 (1), 144-152. doi:10.1111/j.1399-3054.2006.00737.x

Page, V., \& Feller, U. (2015). Heavy metals in crop plants: transport and redistribution processes on the whole plant level. Agronomy, 5 (3), 447-463. doi:10.3390/agronomy5030447

Palmer, C. M., \& Guerinot, M. L. (2009). Facing the challenges of $\mathrm{Cu}$, Fe and $\mathrm{Zn}$ homeostasis in plants. Nature Chemical Biology, 5 (5), 333-340. doi:10.1038/nchembio.166

Palmer, L. J., Dias, D. A., Boughton, B., Roessner, U., Graham, R. D., \& Stangoulis, J. C. R. (2014). Metabolite profiling of wheat (Triticum aestivum L.) phloem exudate. Plant Methods, 10 (21), 1-9.

Palmer, L. J., \& Stangoulis, J. (2018). Changes in the elemental and metabolite profile of wheat phloem sap during grain filling indicate a dynamic between plant maturity and time of day. Metabolites, 8 (3), 1-12. doi:10.3390/metabo8030053

Palmgren, M. G., Clemens, S., Williams, L. E., Kramer, U., Borg, S., Schjorring, J. K., \& Sanders, D. (2008). Zinc biofortification of cereals: problems and solutions. Trends in Plant Science, 13 (9), 464-473. doi:10.1016/j.tplants.2008.06.005

Pascoalino, J. A. L., Thompson, J. A., Wright, G., Franco, F. A., Scheeren, P. L., Pauletti, V., . . . White, P. J. (2018). Grain zinc concentrations differ among Brazilian wheat genotypes and respond to zinc and nitrogen supply. PLoS One, 13 (7), 1-13. doi:10.1371/journal.pone.0199464

Paul, S., Ali, N., Gayen, D., Datta, S. K., \& Datta, K. (2012). Molecular breeding of Osfer2 gene to increase iron nutrition in rice grain. GM Crops $\&$ Food: Biotechnology in Agriculture and the Food Chain, 3 (4), 310-316. doi:10.4161/gmcr.22104

Pearson, J. N., \& Rengel, Z. (1994). Distribution and remobilization of Zn and Mn during grain development in wheat. Journal of Experimental Botany, 45 (281), 1829-1835.

Pearson, J. N., \& Rengel, Z. (1995). Uptake and distribution of 65Zn and 54Mn in wheat grown at sufficient and deficient levels of Zn and Mn: I. During vegetative growth. Journal of Experimental Botany, 46 (7), 
833-839.

Pearson, J. N., Rengel, Z., Jenner, C. F., \& Graham, R. D. (1995). Transport of zinc and manganese to developing wheat grains. Physiologia Plantarum, 95 , 449-455.

Pearson, J. N., Rengel, Z., Jenner, C. F., \& Graham, R. D. (1996). Manipulation of xylem transport affects Zn and mn transport into developing wheat grains of cultured ears. Physiologia Plantarum, 98 , 229-234.

Pedas, P., Schjoerring, J. K., \& Husted, S. (2009). Identification and characterization of zinc-starvationinduced ZIP transporters from barley roots. Plant Physiology and Biochemistry, 47 (5), 377-383. doi:10.1016/j.plaphy.2009.01.006

Perera, I., Fukushima, A., Arai, M., Yamada, K., Nagasaka, S., Seneweera, S., \& Hirotsu, N. (2019). Identification of low phytic acid and high Zn bioavailable rice (Oryza sativa L.) from 69 accessions of the world rice core collection. Journal of Cereal Science, 85 , 206-213. doi:10.1016/j.jcs.2018.12.010

Perera, I., Seneweera, S., \& Hirotsu, N. (2018). Manipulating the phytic acid content of rice grain toward improving micronutrient bioavailability. Rice, 11 (1), 1-13. doi:10.1186/s12284-018-0200-y

Persson, D. P., de Bang, T. C., Pedas, P. R., Kutman, U. B., Cakmak, I., Andersen, B., . . . Husted, S. (2016). Molecular speciation and tissue compartmentation of zinc in durum wheat grains with contrasting nutritional status. New Phytologist, 211 (4), 1255-1265. doi:10.1111/nph.13989

Pfeiffer, W. H., \& McClafferty, B. (2007). HarvestPlus: Breeding crops for better nutrition. Crop Science, $47(53), 88-105$.

Puschenreiter, M., Gruber, B., Wenzel, W. W., Schindlegger, Y., Hann, S., Spangl, B., . . . Oburger, E. (2017). Phytosiderophore-induced mobilization and uptake of $\mathrm{Cd}, \mathrm{Cu}, \mathrm{Fe}, \mathrm{Ni}, \mathrm{Pb}$ and $\mathrm{Zn}$ by wheat plants grown on metal-enriched soils. Environmental and Experimental Botany, 138 , 67-76. doi:10.1016/j.envexpbot.2017.03.011

Raboy, V. (2003). myo-Inositol-1,2,3,4,5,6-hexakisphosphate.Phytochemistry, 64 (6), 1033-1043. doi:10.1016/s0031-9422(03)00446-1

Raboy, V., Young, K. A., Dorsch, J. A., \& Cook, A. (2001). Genetics and breeding of seed phosphorus and phytic acid. Journal of Plant Physiology, 158 (4), 489-497. doi:10.1078/0176-1617-00361

Ramzan, Y., Hafeez, M. B., Khan, S., Nadeem, M., Batool, S., \& Ahmad, J. (2020). Biofortification with Zinc and Iron Improves the Grain Quality and Yield of Wheat Crop. International Journal of Plant Production , 1-10.

Rawat, N., Tiwari, V. K., Singh, N., Randhawa, G. S., Singh, K., Chhuneja, P., \& Dhaliwal, H. S. (2009). Evaluation and utilization of Aegilops and wild Triticum species for enhancing iron and zinc content in wheat. Genetic Resources and Crop Evolution, 56 (1), 53-64. doi:10.1007/s10722-008-9344-8

Rehman, A., Farooq, M., Ozturk, L., Asif, M., \& Siddique, K. H. M. (2018). Zinc nutrition in wheat-based cropping systems. Plant and Soil, 422 (1-2), 283-315. doi:10.1007/s11104-017-3507-3

Rellan-Alvarez, R., Abadia, J., \& Alvarez-Fernandez, A. (2008). Formation of metal-nicotianamine complexes as affected by $\mathrm{pH}$, ligand exchange with citrate and metal exchange. A study by electrospray ionization time-of-flight mass spectrometry. Rapid Communications in Mass Spectrometry, 22 (10), 1553-1562. doi:10.1002/rcm.3523

Rengel, Z., Batten, G. D., \& Crowley, D. E. (1999). Agronomic approaches for improving the micronutrient density in edible portions of field crops. Field Crops Research, 60 (1-2), 27-40.

Ricachenevsky, F. K., de Araujo Junior, A. T., Fett, J. P., \& Sperotto, R. A. (2018). You shall not pass: root vacuoles as a symplastic checkpoint for metal translocation to shoots and possible application to grain nutritional quality. Frontiers in Plant Science, 9 , 1-6. doi:10.3389/fpls.2018.00412 
Ruel, M. T., \& Bouis, H. E. (1998). Plant breeding: a long-term strategy for the control of zinc deficiency in vulnerable populations. The American Journal of Clinical Nutrition, 68 (2), 488-494.

Sadeghzadeh, B. (2013). A review of zinc nutrition and plant breeding. Journal of Soil Science and Plant Nutrition, 13 (4), 905-927.

Sahrawat, A. K., Becker, D., Lutticke, S., \& Lorz, H. (2003). Genetic improvement of wheat via alien gene transfer, an assessment. Plant Science, 165 (5), 1147-1168. doi:10.1016/s0168-9452(03)00323-6

Saltzman, A., Birol, E., Bouis, H. E., Boy, E., De Moura, F. F., Islam, Y., \& Pfeiffer, W. H. (2013). Biofortification: Progress toward a more nourishing future. Global Food Security, 2 (1), 9-17. doi:10.1016/j.gfs.2012.12.003

Sandstead, H. H. (2012). Subclinical zinc deficiency impairs human brain function. Journal of Trace Elements in Medicine and Biology, 26 (2-3), 70-73. doi:10.1016/j.jtemb.2012.04.018

Santa-Marı, G. E., \& Cogliatti, D. H. (1998). The regulation of zinc uptake in wheat plants. Plant Science, $137,1-12$.

Schlemmer, U., Frolich, W., Prieto, R. M., \& Grases, F. (2009). Phytate in foods and significance for humans: food sources, intake, processing, bioavailability, protective role and analysis. Molecular Nutrition \& Food Research, 53 , 330-375. doi:10.1002/mnfr.200900099

Sharma, P., Sheikh, I., Kumar, S., Verma, S. K., Kumar, R., Vyas, P., \& Dhaliwal, H. S. (2018). Precise transfers of genes for high grain iron and zinc from wheat-Aegilops substitution lines into wheat through pollen irradiation. Molecular Breeding, 38 (6), 1-13. doi:10.1007/s11032-018-0836-8

Sharma, P., Sheikh, I., Singh, D., Kumar, S., Verma, S. K., Kumar, R., . . . Dhaliwal, H. S. (2017). Uptake, distribution, and remobilization of iron and zinc among various tissues of wheat-Aegilopssubstitution lines at different growth stages. Acta Physiologiae Plantarum, 39 (8), 1-12. doi:10.1007/s11738-017-2456-z

Shewry, P. R. (2009). Wheat. Journal of Experimental Botany, 60 (6), 1537-1553. doi:10.1093/jxb/erp058

Shitre, A. S., Gadekar, D. A., Ramachandran, V., Bakshi, S., Kumar, V., Vishwakarma, G., \& Das, B. K. (2015). Genotypic variation for phytic acid, inorganic phosphate and mineral contents in advanced breeding lines of wheat (Triticum aestivum L.). Electronic Journal of Plant Breeding, 6 (2), 395-402.

Shukla, V. K., Doyon, Y., Miller, J. C., DeKelver, R. C., Moehle, E. A., Worden, S. E., . . . Urnov, F. D. (2009). Precise genome modification in the crop species Zea mays using zinc-finger nucleases. Nature, 459 (7245), 437-441. doi:10.1038/nature07992

Sillanpää, M. (1982). Micronutrients and the nutrient status of soils: a global study. In Part II Nutrient status by countries (pp. 101-411): Food \& Agriculture Organization of the United Nations.

Simpson, C. J., \& Wise, A. (1990). Binding of zinc and calcium to inositol phosphates (phytate) in vitro. British Journal of Nutrition, 64 (01), 225-232. doi:10.1079/bjn19900024

Sinclair, S. A., \& Kramer, U. (2012). The zinc homeostasis network of land plants. Biochimica et Biophysica Acta, 1823 (9), 1553-1567. doi:10.1016/j.bbamcr.2012.05.016

Singh, R. P., \& Velu, G. (2017). Zinc-biofortified wheat: harnessing genetic diversity for improved nutritional quality . Retrieved from No. 1 (May 2017). CIMMYT, HarvestPlus, and the Global Crop Diversity Trust. Bonn, Germany:

Singh, S. P., Keller, B., Gruissem, W., \& Bhullar, N. K. (2017). RiceNICOTIANAMINE SYNTHASE 2 expression improves dietary iron and zinc levels in wheat. Theoretical and Applied Genetics, 130 (2), 283292. doi:10.1007/s00122-016-2808-x

Sondergaard, T. E., Schulz, A., \& Palmgren, M. G. (2004). Energization of transport processes in plants. roles of the plasma membrane $\mathrm{H}^{+}$-ATPase. Plant Physiology, 136 (1), 2475-2482. doi:10.1104/pp.104.048231 
Sparvoli, F., \& Cominelli, E. (2015). Seed biofortification and phytic acid reduction: a conflict of interest for the plant? Plants (Basel), 4 (4), 728-755. doi:10.3390/plants4040728

Sperotto, R. A., Boff, T., Duarte, G. L., Santos, L. S., Grusak, M. A., \& Fett, J. P. (2010). Identification of putative target genes to manipulate Fe and $\mathrm{Zn}$ concentrations in rice grains. Journal of Plant Physiology, 167 (17), 1500-1506. doi:10.1016/j.jplph.2010.05.003

Stomph, T. J., Choi, E. Y., \& Stangoulis, J. C. (2011). Temporal dynamics in wheat grain zinc distribution: is sink limitation the key? Annals of Botany, 107 (6), 927-937. doi:10.1093/aob/mcr040

Stomph, T. J., Jiang, W., \& Struik, P. C. (2009). Zinc biofortification of cereals: Rice differs from wheat and barley. Trends in Plant Science, 14 (3), 123-124. doi:10.1016/j.tplants.2009.01.001

Takahashi, R., Ishimaru, Y., Shimo, H., Ogo, Y., Senoura, T., Nishizawa, N. K., \& Nakanishi, H. (2012). The OsHMA2 transporter is involved in root-to-shoot translocation of $\mathrm{Zn}$ and $\mathrm{Cd}$ in rice. Plant, Cell and Environment 35 (11), 1948-1957. doi:10.1111/j.1365-3040.2012.02527.x

Tan, J., Wang, J., Chai, T., Zhang, Y., Feng, S., Li, Y., . . Chai, X. (2013). Functional analyses of TaHMA2, a P(1B)-type ATPase in wheat.Plant Biotechnology Journal, 11 (4), 420-431. doi:10.1111/pbi.12027

Tauris, B., Borg, S., Gregersen, P. L., \& Holm, P. B. (2009). A roadmap for zinc trafficking in the developing barley grain based on laser capture microdissection and gene expression profiling. Journal of Experimental Botany, 60 (4), 1333-1347. doi:10.1093/jxb/erp023

Terzano, R., Al Chami, Z., Vekemans, B., Janssens, K., Miano, T., \& Ruggiero, P. (2008). Zinc distribution and speciation within rocket plants (Eruca vesicaria L. Cavalieri) grown on a polluted soil amended with compost as determined by XRF microtomography and micro-XANES. Journal of Agricultural and Food Chemistry, 56 (9), 3222-3231.

Tiong, J., McDonald, G., Genc, Y., Shirley, N., Langridge, P., \& Huang, C. Y. (2015). Increased expression of six ZIP family genes by zinc $(\mathrm{Zn})$ deficiency is associated with enhanced uptake and root-to-shoot translocation of Zn in barley (Hordeum vulgare ). New Phytologist, 207 (4), 1097-1109. doi:10.1111/nph.13413

Tiwari, V. K., Rawat, N., Neelam, K., Kumar, S., Randhawa, G. S., \& Dhaliwal, H. S. (2010). Substitutions of $2 \mathrm{~S}$ and $7 \mathrm{U}$ chromosomes of Aegilops kotschyi in wheat enhance grain iron and zinc concentration. Theoretical and Applied Genetics, 121 (2), 259-269. doi:10.1007/s00122-010-1307-8

Uauy, C., Distelfeld, A., Fahima, T., Blechl, A., \& Dubcovsky, J. (2006). A NAC gene regulating senescence improves grain protein, Zn, and Fe content in wheat. Science, 314 (5803), 1298-1301.

Vatansever, R., Filiz, E., \& Eroglu, S. (2017). Genome-wide exploration of metal tolerance protein (MTP) genes in common wheat (Triticum aestivum ): insights into metal homeostasis and biofortification.Biometals, 30 (2), 217-235. doi:10.1007/s10534-017-9997-x

Velu, G., Herrera, C. L., Guzman, C., Huerta, J., Payne, T., \& Singh, R. P. (2019). Assessing genetic diversity to breed competitive biofortified wheat with enhanced grain $\mathrm{Zn}$ and Fe concentrations.Frontiers in Plant Science, 9 , 1-11. doi:10.3389/fpls.2018.01971

Velu, G., Ortiz-Monasterio, I., Cakmak, I., Hao, Y., \& Singh, R. P. (2014). Biofortification strategies to increase grain zinc and iron concentrations in wheat. Journal of Cereal Science, 59 (3), 365-372. doi:10.1016/j.jcs.2013.09.001

Velu, G., Singh, R. P., Cardenas, M. E., Wu, B., Guzman, C., \& Ortiz-Monasterio, I. (2017). Characterization of grain protein content gene (GPC-B1) introgression lines and its potential use in breeding for enhanced grain zinc and iron concentration in spring wheat. Acta Physiologiae Plantarum, 39 (9). doi:10.1007/s11738017-2509-3

Velu, G., Singh, R. P., Crespo-Herrera, L., Juliana, P., Dreisigacker, S., Valluru, R., . . Joshi, A. K. (2018). Genetic dissection of grain zinc concentration in spring wheat for mainstreaming biofortification in CIMMYT 
wheat breeding. Scientific Reports, 8 (1), 1-10. doi:10.1038/s41598-018-31951-z

Velu, G., Singh, R. P., Huerta-Espino, J., Peña-Bautista, R. J., \& Ortiz-Monasterio, I. (2011). Breeding for enhanced zinc and iron concentration in CIMMYT spring wheat germplasm. Czech Journal of Genetics and Plant Breeding, 47 (Special Issue), 174-177.

Velu, G., Tutus, Y., Gomez-Becerra, H. F., Hao, Y., Demir, L., Kara, R., . . . Cakmak, I. (2017). QTL mapping for grain zinc and iron concentrations and zinc efficiency in a tetraploid and hexaploid wheat mapping populations. Plant and Soil, 411 , 81-99. doi:10.1007/s11104-016-3025-8

Venegas, J. P., Graybosch, R. A., Wienhold, B., Rose, D. J., Waters, B. M., Baenziger, P. S., . . Amand, P. S. (2018). Biofortification of hard red winter wheat by genes conditioning low phytate and high grain protein Concentration. Crop Science, 58 (5), 1942-1953. doi:10.2135/cropsci2018.03.0175

Wang, Y. X., Specht, A., \& Horst, W. J. (2011). Stable isotope labelling and zinc distribution in grains studied by laser ablation ICP-MS in an ear culture system reveals zinc transport barriers during grain filling in wheat. New Phytologist, 189 (2), 428-437. doi:10.1111/j.1469-8137.2010.03489.x

Waters, B. M., \& Sankaran, R. P. (2011). Moving micronutrients from the soil to the seeds: genes and physiological processes from a biofortification perspective. Plant Science, 180 (4), 562-574. doi:10.1016/j.plantsci.2010.12.003

Waters, B. M., Uauy, C., Dubcovsky, J., \& Grusak, M. A. (2009). Wheat (Triticum aestivum ) NAM proteins regulate the translocation of iron, zinc, and nitrogen compounds from vegetative tissues to grain. Journal of Experimental Botany, 60 (15), 4263-4274. doi:10.1093/jxb/erp257

White, J. G., \& Zasoski, R. J. (1999). Mapping soil micronutrients.Field Crops Research, 60 , 11-26.

White, P. J., \& Broadley, M. R. (2005). Biofortifying crops with essential mineral elements. Trends in Plant Science, 10 (12), 586-593. doi:10.1016/j.tplants.2005.10.001

White, P. J., \& Broadley, M. R. (2011). Physiological limits to zinc biofortification of edible crops. Frontiers in Plant Science, 2 (80), 1-11. doi:10.3389/fpls.2011.00080

Wilkinson, S., Corlett, J. E., Oger, L., \& Davies, W. J. (1998). Effects of xylem pH on transpiration from wild-type and flacca tomato leaves: a vital role for abscisic acid in preventing excessive water loss even from well-watered plants. Plant Physiology, 117 (2), 703-709.

Xia, H., Xue, Y., Liu, D., Kong, W., Xue, Y., Tang, Y., . . Mei, P. (2018). Rational application of fertilizer nitrogen to soil in combination with foliar $\mathrm{Zn}$ spraying improved $\mathrm{Zn}$ nutritional quality of wheat grains. Frontiers in Plant Science, 9 , 1-13. doi:10.3389/fpls.2018.00677

Xu, Y., An, D., Liu, D., Zhang, A., Xu, H., \& Li, B. (2012). Molecular mapping of QTLs for grain zinc, iron and protein concentration of wheat across two environments. Field Crops Research, 138 , 5762. doi:10.1016/j.fcr.2012.09.017

Xue, Y. F., Eagling, T., He, J., Zou, C. Q., McGrath, S. P., Shewry, P. R., \& Zhao, F. J. (2014). Effects of nitrogen on the distribution and chemical speciation of iron and zinc in pearling fractions of wheat grain. Journal of Agricultural and Food Chemistry, 62 (20), 4738-4746. doi:10.1021/jf500273x

Xue, Y. F., Yue, S. C., Zhang, Y. Q., Cui, Z. L., Chen, X. P., Yang, F. C., . . Zou, C. Q. (2012). Grain and shoot zinc accumulation in winter wheat affected by nitrogen management. Plant and Soil, 361 (1-2), 153-163. doi:10.1007/s11104-012-1510-2

Yang, R., Juhasz, A., Zhang, Y., Chen, X., Zhang, Y., She, M., . . Ma, W. (2018). Molecular characterisation of the NAM-1 genes in bread wheat in Australia. Crop and Pasture Science, 69 (12), 1173-1181. doi: $10.1071 / \operatorname{cp} 18273$ 
Yaseen, M. K., \& Hussain, S. (2020). Zinc-biofortified wheat required only a medium rate of soil zinc application to attain the targets of zinc biofortification. Archives of Agronomy and Soil Science (just-accepted).

Yoneyama, T., Ishikawa, S., \& Fujimaki, S. (2015). Route and regulation of zinc, cadmium, and iron transport in rice plants (Oryza sativaL.) during vegetative growth and grain filling: metal transporters, metal speciation, grain cd reduction and $\mathrm{Zn}$ and Fe biofortification.International Journel of Molecular Science, 16 (8), 19111-19129. doi:10.3390/ijms160819111

Zee, S. Y. (1972). Vascular tissue and transfer cell distribution in the rice spikelet. Australian Journal of Biological Sciences, 25 (2), 411-414.

Zee, S. Y., \& O'Brien, T. P. (1970). A special type of tracheary element associated with "xylem discontinuity" in the floral axis of wheat. Australian Journal of Biological Sciences, 23 , 783-791.

Zhang, T., Sun, H., Lv, Z., Cui, L., Mao, H., \& Kopittke, P. M. (2018). Using synchrotron-based approaches to examine the foliar application of $\mathrm{ZnSO} 4$ and $\mathrm{ZnO}$ nanoparticles for field-grown winter wheat. Journal of Agricultural and Food Chemistry, 66 (11), 2572-2579. doi:10.1021/acs.jafc.7b04153

Zhao, R. R., Qu, B. Y., Tong, Y. P., \& Zou, C. Q. (2019). Iron and zinc accumulation in winter wheat regulated by NICOTIANAMINE SYNTHASEresponded to increasing nitrogen levels. Journal of Plant Nutrition, 42 (14), 1624-1636. doi:10.1080/01904167.2019.1630427

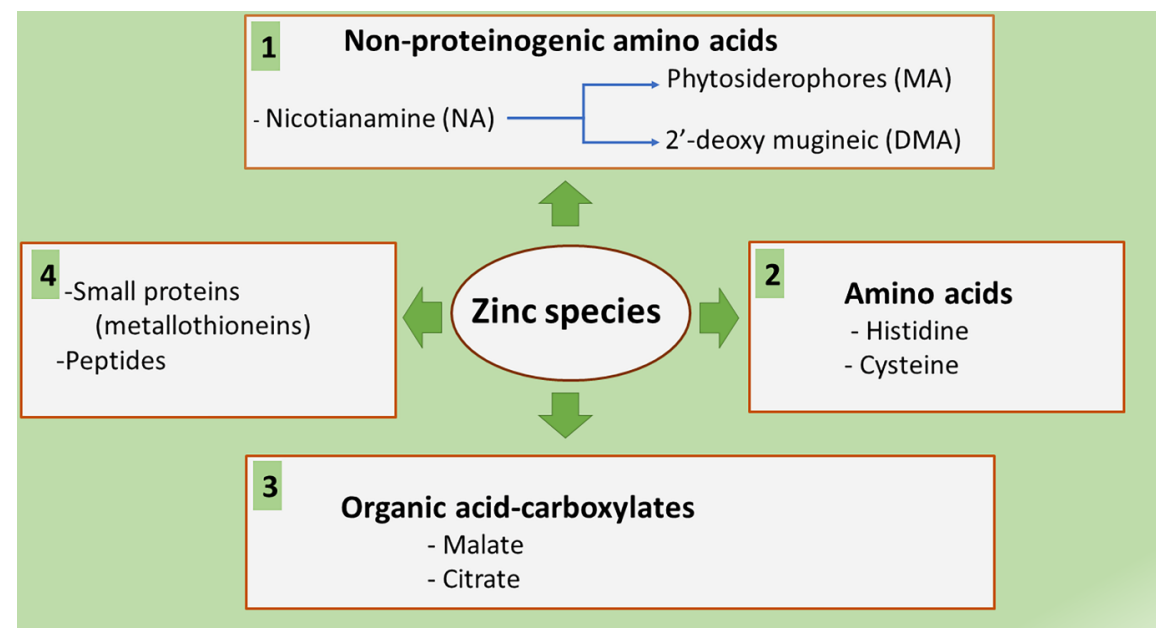

FIGURE 1. Low molecular weight Zn complexes commonly found in plants. Zinc can complex with N-, S- and O- electron donors in organic ligands. Zinc complexing agents are grouped into four main categories: 1) non-proteinogenic amino acids such as nicotianamine (NA), and chelating compounds derived from NA, including the mugineic acid family of phytosiderophores (MA) and 2'-deoxy mugineic (DMA); 2) amino acids including histidine and cysteine; and, 3) organic acid-carboxylates including malate and citrate; and 4) small proteins (metallothioneins) and peptides. 


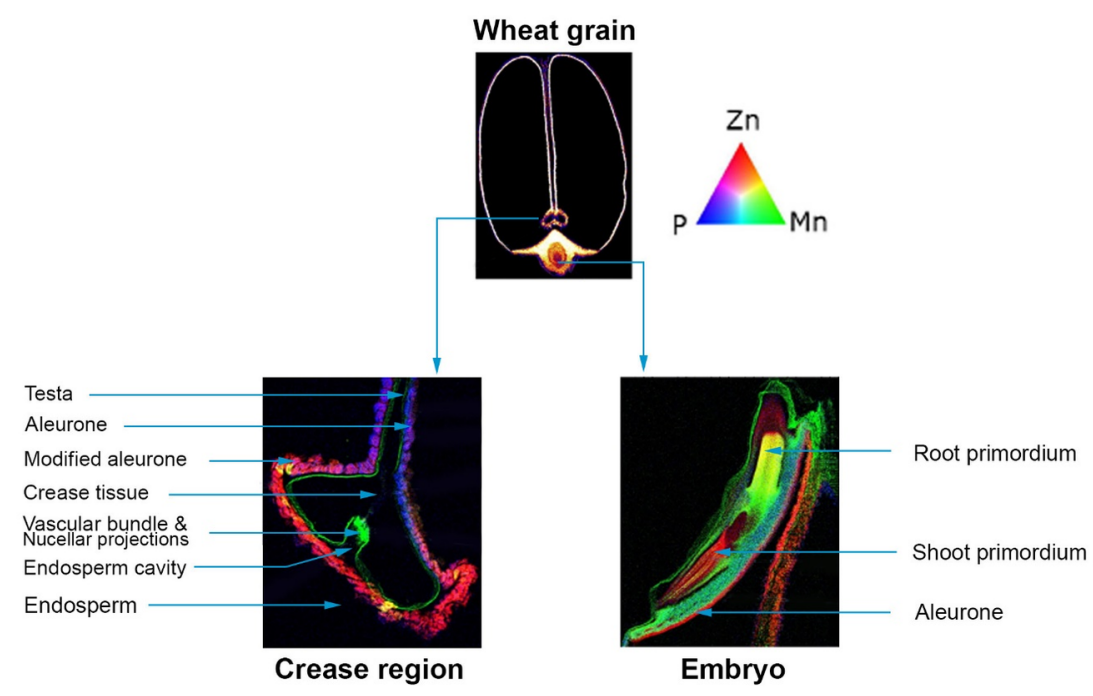

FIGURE 2. X-ray fluorescence microscopy (XFM) elemental map of transverse and longitudinal sections of wheat grain. Different locations of the crease region and the embryo of the wheat grain are elaborated. Tricolour RGB colour maps show the co-localization of Zn (red), P (blue) and Mn (green) in the embryo and crease region. Overlap (correlation) between $\mathrm{Mn}$ (green) and $\mathrm{Zn}$ (red) is shown as yellow (unpublished data).

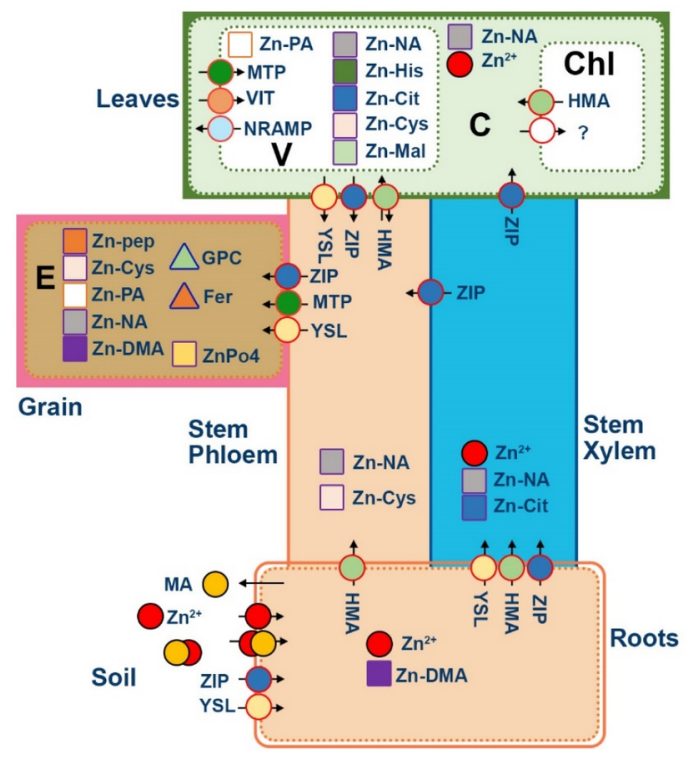

FIGURE 3. A simplified diagram of the putative mechanism of speciation-mediated Zn uptake, transport, and grain loading in wheat. Zinc in the soil solution enters roots as free $\mathrm{Zn}^{2+}$ or as a complex with 
mugineic acid (MA), regulated by yellow stripe like (YSL) and Zn/Fe-regulated (ZIP) transporter families. Once taken up, $\mathrm{Zn}$ is either translocated in the form of free $\mathrm{Zn}^{2+}$, or as $\mathrm{Zn}$ complexes, or stored as $\mathrm{Zn}$ complexes. In the wheat root, Zn preferentially binds with nicotianamine (NA) and 2'-deoxy mugineic (DMA) facilitating translocation and inter-cellular homeostasis. Movement of $\mathrm{Zn}$ is powered by different transporter families including ZIP, YSL, $\mathrm{P}_{1 \mathrm{~B}}$-ATPases: also known as heavy metal ATPases (HMA), natural resistance associated macrophage protein (NRAMP), metal tolerance proteins (MTP) and vascular iron transporters (VIT), which are located in the plasma or organelle membranes of the cell. Different Zn speciation, and transporter families, function in different areas of the wheat plant to regulate $\mathrm{Zn}$ translocation. Chelated or free $\mathrm{Zn}^{2+}$ is sequestered into the leaf vacuole (V) and chloroplast (Chl) and remobilized when needed. MTP and VIT transporter families are involved in sequestering $\mathrm{Zn}$ into the vacuole while transporters involved in sequestering Zn into the chloroplast are not clear. NRAMP and HMA family transporters are responsible for liberating stored $\mathrm{Zn}$ from the leaf vacuole and the chloroplast back into the cytoplasm during remobilization to be loaded into the phloem. In the leaf vacuole, $\mathrm{Zn}$ is complexed with NA, histidine (His), citrate (Cit), cysteine (Cys), malate (Mal) and PA. Zn loading in the grain is mainly regulated by ZIP, MTP and YSL transporter families. The majority of the $\mathrm{Zn}$ in the wheat endosperm (E) forms complexes with PA, Cys, peptides (Pep), $\mathrm{ZnPO}_{4}, \mathrm{NA}$ and DMA. The ferritin gene (Fer) and grain protein genes (GPC), also known as no apical meristem (NAM) genes, also regulate endosperm grain Zn content. 